\title{
Public Participation in Nuclear Waste Management: A COMPARATIVE ANALYSIS OF THE SWEDISH AND CANADIAN PROCESSES
}

\author{
By \\ Rosanne Camacho \\ BSc (Env), University of Guelph, 2002
}

\author{
A thesis \\ presented to Ryerson University \\ in partial fulfillment of the \\ requirement for the degree of \\ Master of Applied Science \\ in the Program of
}

Environmental Applied Science and Management

Toronto, Ontario, Canada, 2005

(C) Rosanne Camacho, 2005 


\section{UMI Number: EC53034}

\section{All rights reserved \\ INFORMATION TO USERS}

The quality of this reproduction is dependent upon the quality of the copy submitted. Broken or indistinct print, colored or poor quality illustrations and photographs, print bleed-through, substandard margins, and improper alignment can adversely affect reproduction.

In the unlikely event that the author did not send a complete manuscript and there are missing pages, these will be noted. Also, if unauthorized copyright material had to be removed, a note will indicate the deletion.

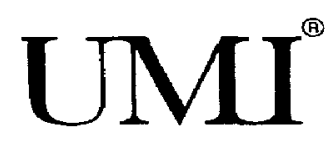

UMI Microform EC53034

Copyright 2008 by ProQuest LLC

All rights reserved. This microform edition is protected against unauthorized copying under Title 17, United States Code.

ProQuest LLC

789 East Eisenhower Parkway

P.O. Box 1346

Ann Arbor, MI 48106-1346 


\section{Author's Declaration}

I hereby declare that I am the sole author of this thesis.

I authorize Ryerson University to lend this thesis or dissertation to other institutions or individuals for the purpose of scholarly research.

I further authorize Ryerson University to reproduce this thesis or dissertation by photocopying or by other means, in total or in part, at the request of other institutions or individuals for the purpose of scholarly research.

$+$ 


\section{BORROWer's PAge}

Ryerson University requires the signatures of all persons using or photocopying this thesis. Please sign below, and provide address and date.

\begin{tabular}{|c|c|c|}
\hline NAME & DATE & $\zeta \quad$ a $\quad \overline{\mathbf{E}}$ \\
\hline , & $1 e_{T}, 23 / 06$ & $-\min <<2$ \\
\hline & & \\
\hline & & \\
\hline & & \\
\hline & & \\
\hline & & \\
\hline & & 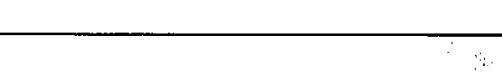 \\
\hline & & \\
\hline & & \\
\hline & & \\
\hline & & \\
\hline & & \\
\hline & & \\
\hline & & \\
\hline & & \\
\hline & & \\
\hline & & \\
\hline & & \\
\hline & & \\
\hline & & \\
\hline & & \\
\hline & & \\
\hline & & \\
\hline & & \\
\hline & & \\
\hline & & \\
\hline
\end{tabular}




\section{Abstract \\ Public Participation in Nuclear Waste Management: A Comparative Analysis of the Swedish and Canadian Processes \\ Rosanne Camacho \\ Environmental Applied Science and Management \\ Masters of Applied Science, Ryerson University, 2005}

This thesis addresses the issue of public participation in the implementation of nuclear waste management (NWM) strategies by comparing the NWM programs of Sweden and Canada. It begins with a comparison of the progress and current status of the Swedish and Canadian NWM programs, which illustrates that the Swedish program is further ahead in terms of obtaining approval for a disposal method. Next, quantitative analyses were performed on three measures of public engagement, which revealed that the proponents of Sweden's NWM program have focused on public participation much more their Canadian counterparts. Lastly, a comparison was made between the level of public awareness regarding nuclear waste and public support for the NWM programs of each country. The analyses indicated that there is a greater level of both public awareness of the nuclear waste issue and public support for the NWM program in Sweden than there is in Canada. 


\section{ACKnowledgements}

I would like to extend my deepest gratitude to my thesis advisor, Dr. Ronald Pushchak, for his constant support, encouragement, understanding and advice during the preparation of my thesis and throughout my education at Ryerson.

I am also indebted to Gunilla Leroux for her time and effort in translating all my Swedish documents.

I would like to especially thank my parents, Feliberto and Olivia Camacho for their unconditional love and support. To my siblings, Ghiselle, Jerome, Irene and Maurice... you guys drive me nuts half the time, but growing up without you would not have been the same. I'm sure most of the time it doesn't show, but I really love and appreciate you all.

Lastly, a great big thank you goes out to my 'dahlings', Jessamyn and Lili for always being there for me, keeping me in line, keeping me sane and providing me with the occasional much needed distractions. 


\section{TABLE OF CONTENTS}

Author's Declaration ....................................................................................................................i

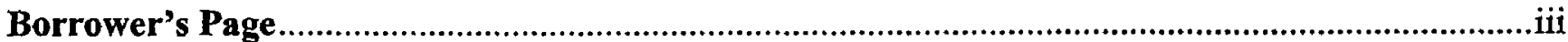

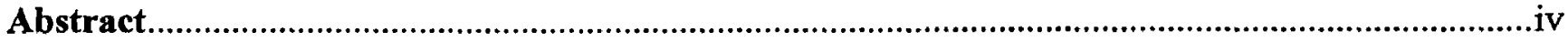

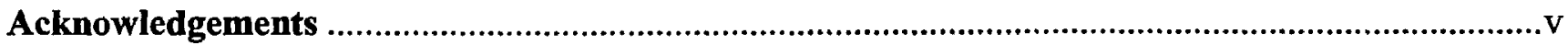

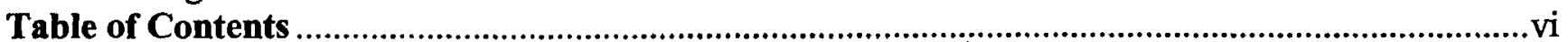

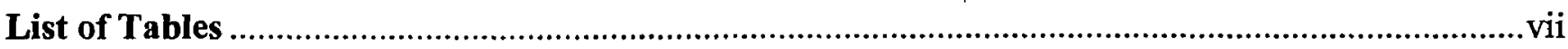

List of Figures...............................................................................................................................

Chapter 1: Introduction .........................................................................................................

$1.1 \quad$ Background and Context...........................................................................................

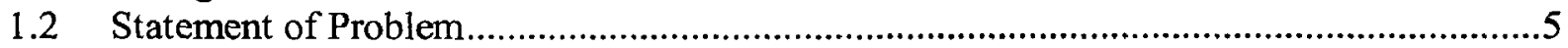

1.3 Research Objectives...............................................................................................

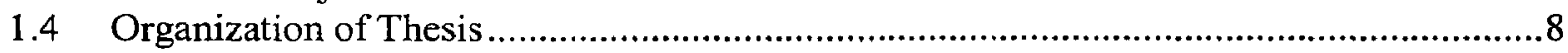

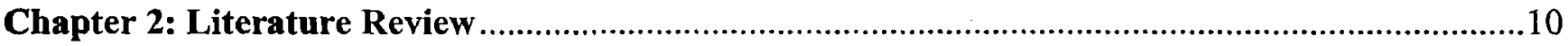

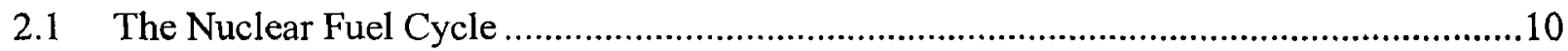

2.2 Nuclear Fuel Waste.....................................................................................................12

2.3 Sweden's Nuclear Waste Management Program..................................................................15

2.4 Canada's Nuclear Waste Management Program ...............................................................21

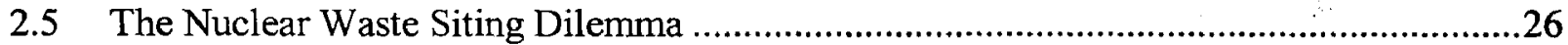

2.5.1 Public Opposition - Not-In-My-Backyard ……….............................................27

2.5.2 Roots of Public Opposition ...................................................................................29

2.5.3 Overcoming Public Opposition ................................................................................35

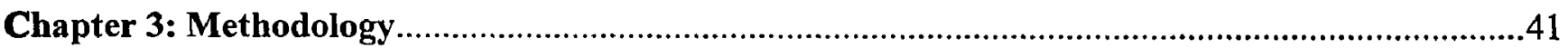

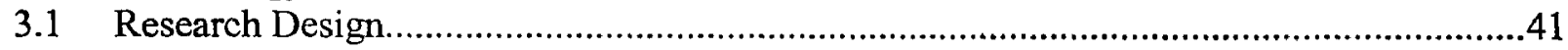

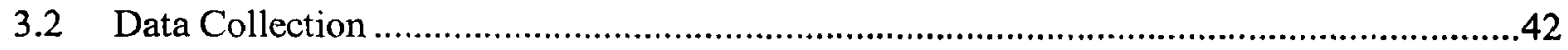

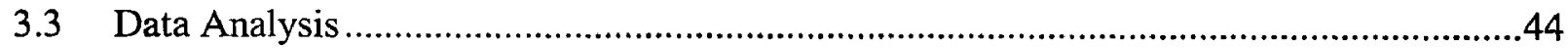

3.4 Assumptions and Limitations .......................................................................................46

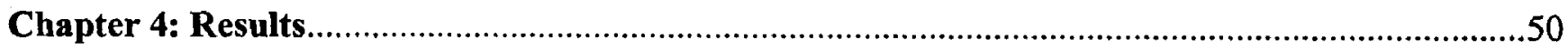

4.1 Progress and Current Status of NWM Programs ...........................................................50

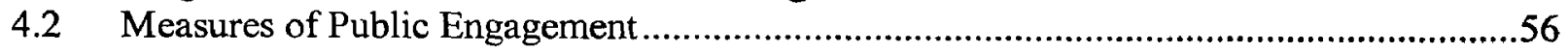

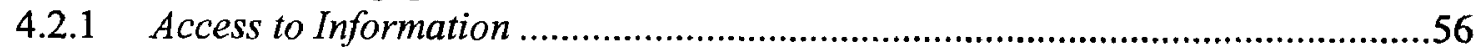

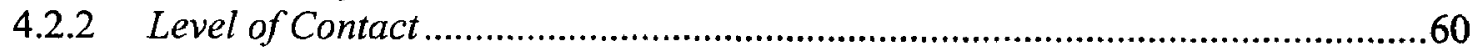

4.2.3 Financial Resources Devoted to Public Engagement......................................65

4.3 Public Awareness of Nuclear Waste Issues and

Support for NWM Programs......................................................................................67

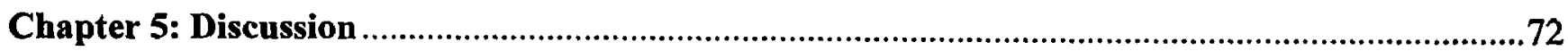

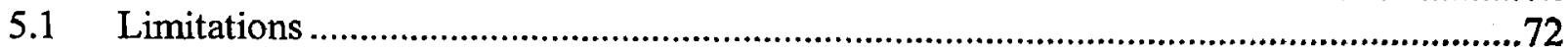

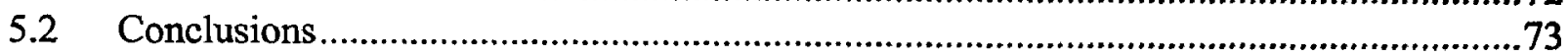

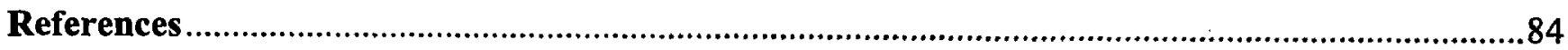




\section{LIST OF TABLES}

Table 1. Known recoverable resources of uranium 10

Table 2. Support for nuclear energy in Sweden and Canada

Table 3. Number of information materials published or released by SKB regarding the Swedish nuclear waste management program

Table 4. Number of information materials published or released by the EA Panel regarding the Canadian Panel Review of the Nuclear Fuel Waste Management and Disposal Concept .............................57

Table 5. Annual number of visitors to SKB's Äspo Hard Rock Laboratory between 1994-2004 ....................58

Table 6. Annual number of visitors to AECL's Underground Research Laboratory between 1991-2001...........58

Table 7. Number of events at which SKB has made contact with the public since 1992 ..........................62

Table 8. Number of events at which the EA Panel made contact with the public during the Panel Review of the Nuclear Fuel Waste Management and Disposal Concept................................................64

Table 9. Funding for the public engagement activities in Sweden and the EA Panel Review in Canada...........66 


\section{LIST OF FIGURES}

Figure 1. World nuclear electricity production and share of total electricity production...........................2

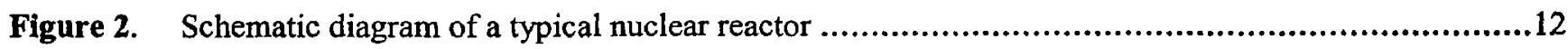

Figure 3. Basic layout of the deep repository based on the KBS-3 Method .....................................18

Figure 4. Locations of proposed detailed site investigation municipalities ................................................20

Figure 5. Major developments in Sweden's nuclear waste management program ...................................51

Figure 6. Major developments in Canada's nuclear waste management program ..................................52

Figure 7. Graphical comparison of the number of visits to SKB's Äspo HRL and AECL's URL .................60

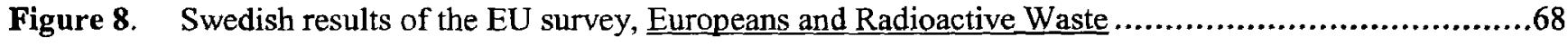

Figure 9. Results of the survey, Public Attitudes to Nuclear Waste and the NWMO Project .............................68

Figure 10. Results of SKB opinion survey regarding a deep repository ...........................................70

Figure 11. Survey results regarding the handling of nuclear waste in Canada.........................................70 


\section{INTRODUCTION}

\subsection{Background and Context}

Nuclear waste management is a significant problem faced by all nations that employ a nuclear energy industry. The question of what to do with the highly radioactive waste produced by commercial nuclear generators has been deliberated for the past several decades (Carter, 1987; Dunlap et al., 1993; Flynn et al., 1992; Gerrard, 1994; Easterling and Kunreuther, 1995; Kemp, 1992; Kunreuther et al., 1988; Murdock et al., 1983; Rabe, 1994; Slovic et al., 1991). Yet, despite the, in some cases, billions of dollars that have been spent on siting attempts (Freudenburg, 2004; Gerrard, 1994), no country has yet been able to implement a permanent nuclear fuel waste disposal facility (Kraft, 2000; Krauskopf, 1990; Kuhn and Murphy, 2001; Rabe, 1994).

Nuclear power provides numerous benefits such as relatively cheap electricity, economic development and employment for the benefit of society. It currently produces approximately $16 \%$ of the world's electricity, with over 440 nuclear power reactors operating in 31 countries, and a total capacity of over 360,000 MWe (World Nuclear Association, 2004). Seventeen countries currently rely on nuclear energy for at least a quarter of their electricity needs (WNA, 2004); while in France over $75 \%$ of the electricity is generated by nuclear energy (Wilson, 1996). The reliance on nuclear energy to produce electricity has increased steadily over the past thirty years (Figure 1).

On the other hand, nuclear power production creates, as a by-product, nuclear wastes that will remain toxic and dangerously radioactive for thousands of years (Flynn et al., 1995). 
Although other sources of power, such as coal, oil, natural gas and hydro, present their own problems, it is said that none are as controversial as those presented by nuclear energy (Carter, 1987). Furthermore, although there have been issues identified in all stages of the nuclear fuel cycle, the disposal of nuclear wastes is considered by far the most "controversial and contentious area of nuclear policy" (Lidskog and Sundqvist, 2004, pg. 252).

\section{Nuclear Electricity Production and Share of Total Electricity Production}

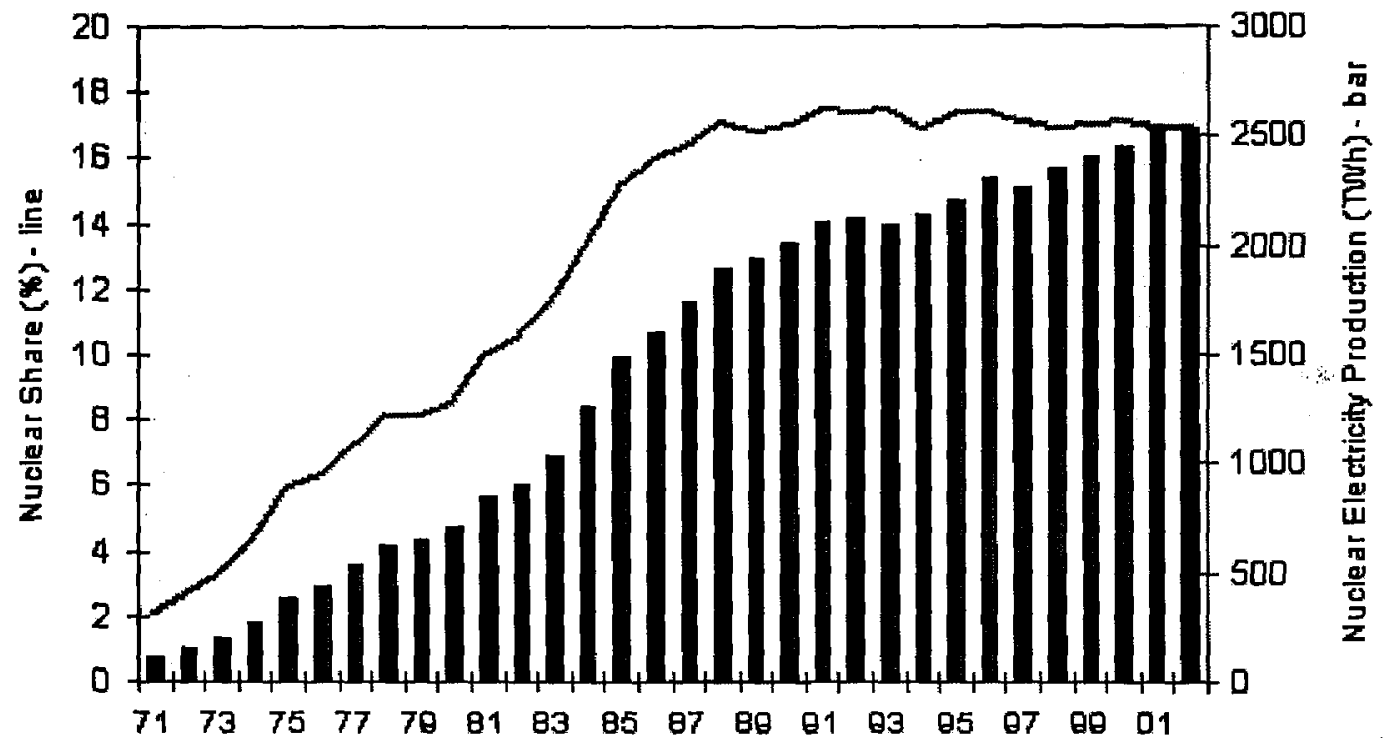

Figure 1. World nuclear electricity production and share of total electricity production (WNA, 2004)

In most countries, spent nuclear fuel along with other high-level waste (HLW) is placed in interim storage in facilities located at nuclear reactor sites (Decamps et al., 1997). Although this current method is expected to be safe for a lengthy period (Flynn et al., 1992), many countries are now looking towards geological disposal as a final solution to the problem of nuclear waste (Flynn et al., 1995; Carter, 1987; CEAA; 1998; Decamps et al., 1997; Soloway, 2003). In the United States, for instance, the need for a permanent solution to the problem of 
nuclear waste became apparent during the mid-1970s when original plans for reprocessing spent fuel failed (Easterling and Kunreuther, 1995), while in Canada permanent disposal was identified by an expert panel in 1977 to be the preferred method, noting that the "waste should not be allowed to accumulate indefinitely in interim storage" (AECL, 1994, pg. 2).

Three reasons for constructing a geological repository have been presented by Krauskopf (1990):

First, waste kept in containers near the earth's surface is always subject to massive release by acts of nature - violent storms or earthquakes - or by sabotage, or by carelessness on the part of those supposedly watching over it. Second, if a method of disposal cannot be demonstrated soon the nuclear energy industry is in deep trouble: opponents can claim that waste is an insoluble problem, hence that production of more should be stopped at once. And third, in a more philosophical vein, the waste that we do not dispose of now will remain as an unjustified burden for our children and grandchildren to cope with"

(Krauskopf, 1990, pg. 249)

Krauskopf's second argument is one that can repeatedly be found in literature. Flynn et al. (1992) have described the nuclear industry's fears of a grim future should an effective management program not be found. Other arguments that have been made for the case of geological disposal include moral obligation. Carter (1997) for instance contends that the United States, being the nation that "started the nuclear endeavor", should lead the world in dealing with its dangerous by-products. Recent events, such as the September 11, 2001 attacks on the World Trade Center in New York City have also brought security issues to the forefront with respect to nuclear storage facilities, most of which are located aboveground (Haussman et al., 2003; Stone, 2004). This has prompted even greater consideration of geological disposal as a nuclear waste management option, particularly in the United States where the attacks prompted Congress to approve Yucca Mountain as the country's repository site, despite the state of Nevada's objections (Stone, 2004). In fact, the elimination of 
terrorism threats became one of the US Department of Energy's primary arguments for a geological repository.

It has been widely documented that the failure to site facilities for nuclear and indeed, all hazardous waste in general, can be attributed to public opposition (Dunlap et al., 1993; Easterling and Kunreuther, 1995; Hine et al., 1997; Slovic et al., 1991). Gerrard (1994), for instance, reports that in 1975 , the city of Minnesota was given $\$ 3.7$ million by the US Environmental Protection Agency (EPA) to site a hazardous waste landfill, only to give it back three years later after it encountered significant local opposition at each of the 16 potential sites that had been identified. Similarly, in 1990, protesters against a potential site of a low-level radioactive waste (LLRW) repository in Allegany County, New York prevented state officials from proceeding to the site by erecting roadblocks and barricading a bridge (Inhaber, 1994). State officials in Nevada even filed lawsuits and attempted to create new legislation in an attempt to block the federal Department of Energy from conducting suitability tests at Yucca Mountain, which had been identified as the site of geologic repository for the United States' spent nuclear waste (Easterling, 1992).

Early efforts to site nuclear waste repositories relied on technical solutions that were presented by government officials and nuclear authorities using the so-called DecideAnnounce-Defend (DAD) approach (Rabe, 1994). This "top-down" approach consisted of "a nonpublic process of choosing a particular site, announcing this choice publicly, and then mounting whatever effort seems necessary to defend and secure approval of, or at least acquiescence to, this choice" (Munton, 1996, pg. 11). It is only in recent years that public support for a facility has been recognized as a necessity in the site selection process (Bjarnadóttir and Hilding-Rydevik, 2001; Freudenburg, 2004). 
This study examines the nuclear waste management strategies of two different countries:

Sweden and Canada. Particular attention is paid to Sweden's efforts to engage the public in order to gain acceptance and support for its proposed nuclear waste disposal strategy, and what the effect these efforts have had on the progress of its nuclear waste siting process. Sweden was particularly chosen for this study as it is widely accepted that among nuclear producing nations, it is furthest along in siting a high-level radioactive waste (HLRW) facility using a voluntary process. It is hoped that this research will provide valuable insight to other nations struggling with the nuclear waste siting dilemma.

\subsection{Statement of Problem}

Although large amounts of money have been poured into the scientific and engineering aspects of high-level radioactive waste disposal, virtually nothing has been done to actively enlist the public in the siting process or to collaborate with the public in forging a solution.

(Flynn et al., 1992, pg. 42)

The above statement illustrates the problem that this research addresses: to examine the role of meaningful public participation in the successful siting of a nuclear waste repository. Whereas previous siting attempts have focused on providing a technological solution to the problem of nuclear waste, it is only in recent years that policy-makers have begun to recognize the importance of public acceptance in a successful siting strategy. This research addresses this problem by examining the measures that have been taken by one country's nuclear authorities to engage and communicate with its citizenry regarding its nuclear waste disposal strategy. 
This research can provide valuable insight on how to avoid future siting impasses. Although public opposition to the siting of nuclear waste facilities has become a fairly common topic in research literature (Brotzen, 1995; Flynn et al., 1995; Freudenburg, 2004; Hine et al., 1997; Inhaber, 1991; Kraft, 2000; Kuhn, 1998; Kunreuther, 1996; Rabe, 2000; Slovic et al., 1991), it continues to be a major problem for regulatory authorities in nations producing nuclear waste. Understanding how one country has been able to gain acceptance of a nuclear waste repository will provide valuable insight to other countries with nuclear waste programs. Indeed, it will likely prove useful in the siting of any hazardous waste facility.

It is particularly relevant to Canada, where nearly thirty years of research and development has yet to produce an acceptable permanent disposal solution (Hine et al., 1997; Kuhn, 1998). Like many other nuclear countries, historically, Canada's nuclear establishment has focused its research on the scientific and technological aspects of a proposed geological repository, with little attention being paid to social science issues, despite the public's apprehension regarding nuclear issues (Summers and Hine, 1997). Prior to 2002, public participation with regards to nuclear waste management was rather limited, consisting mainly of scoping meetings and public hearings, as per the requirements of the Canadian Environmental Assessment (EA) process.

In 1998, the Nuclear Fuel Waste Management and Disposal Concept Environmental Assessment (EA) Panel submitted its report to the Canadian government. Following the Panel's finding that the concept submitted by Atomic Energy of Canada Limited (AECL) was socially unacceptable, in 2002 the Canadian government passed the Nuclear Fuel Waste Act, which is considered a major step towards finding a solution to Canada's nuclear waste .problem (NRCAN, 2002). This new legislation has created an entity from Canada's nuclear 
producers, called the Nuclear Waste Management Organization, whose mandate is "to develop collaboratively with Canadians a management approach for the long-term care of Canada's used nuclear fuel that is socially acceptable, technically sound, environmentally responsible and economically feasible" (NWMO, 2003, pg. 2). The fact that the NWMO has emphasized a collaborative approach is another reason for choosing Sweden for this study. It would appear that the NWMO is cognizant of the nature and level of effort with respect to public participation that would be required to implement a successful nuclear waste management program. This research will add to the NWMO's understanding of the most sọcially acceptable method of managing Canada's nuclear fuel waste. It can also provide valuable insight to the Government of Canada on how best to implement the chosen method.

\subsection{Research Objectives}

This thesis is based on a comparative analysis of the public engagement aspect of the nuclear waste management strategies of two different countries: Sweden and Canada. While Canada has run into significant delays in implementing a permanent disposal solution for its spent nuclear fuel, Sweden appears to have been more successful; applications to construct a nuclear waste encapsulation plant and geologic repository are expected to be filed within the next five years. The purpose of this research is to determine the role of effective public engagement in a successful nuclear waste management program and siting process. It is centered on the following three objectives:

1) to show that the Swedish nuclear authorities have emphasized the role of public engagement in the development and implementation of its nuclear waste disposal strategy; 
2) to prove that the progress that has been made in Sweden towards siting a geological repository for spent nuclear fuel waste can be attributed to the public engagement measures that the Swedish nuclear authorities have put in place; and

3) to demonstrate that the lack and/or inadequacy of these public engagement measures in the Canadian nuclear waste management program is accountable for the continued opposition to and consequent delay in siting a geological repository in Canada.

\subsection{Organization of Thesis}

This thesis is organized into five chapters. Chapter 1 provides an introduction to the study, including the research context, problem and objectives. Background information is provided in Chapter 2, which includes information about the nuclear fuel cycle and nuclear waste, as well as a description of the nuclear waste management strategies of Sweden and Canada.

Chapter 2 also includes a review of the literature pertaining to the nuclear waste siting dilemma. In Chapter 3 methods employed by the study are outlined. The design of this research includes both a qualitative and quantitative component, with the study being conducted in three parts. The first part of the study, a qualitative comparison of the progress $\therefore$ and current status of the nuclear waste management programs of Sweden and Canada, is based on a review of documents from a variety of primary and secondary sources. The second part of the analysis consists of a quantitative analysis of specific measures of public engagement. The data for this part of the study are derived mainly from primary sources. The third part of the study examines the effectiveness of each country's public engagement activities using surveys on attitudes towards nuclear waste management. In Chapter 4 the 
results of the analyses conducted for this are presented. The final chapter discusses the results of the analyses and presents the conclusions of this research. 


\section{BACKGROUND AND LITERATURE REVIEW}

\section{$2.1 \quad$ The Nuclear Fuel Cycle}

The nuclear fuel cycle can be considered as having two stages, often referred to as the "front end" and the "back end" (WNA, 2001). The front end of the cycle consists of the production of nuclear fuel (Rouben, 1998).

Nuclear fuel is derived from uranium, a naturally radioactive element found in the earth's crust (WNA, 2001). Australia has the largest known reserves of uranium, followed by Kazakhstan and Canada (see Table 1). Canada, however, is the largest producer of uranium, making up approximately $30 \%$ of the world market (Rouben, 1998).

Table 1. Known recoverable resources of uranium

\begin{tabular}{lcc}
\hline \multicolumn{1}{c}{ Country } & Tonnes U & Percentage of World \\
Australia & 863,000 & $28 \%$ \\
Kazakhstan & 472,000 & $15 \%$ \\
Canada & 437,000 & $14 \%$ \\
South Africa & 298,000 & $10 \%$ \\
Namibia & 235,000 & $8 \%$ \\
Brazil & 197,000 & $6 \%$ \\
Russian Fed. & 131,000 & $4 \%$ \\
USA & 104,000 & $3 \%$ \\
Uzbekistan & 103,000 & $3 \%$ \\
\cline { 2 - 2 } World total & $3,107,000$ & \\
\hline
\end{tabular}

Source: OECD NEA \& IAEA, Uranium 2001: Resources, Production and Demand, presented in Hore-Lacy, 2003.

Uranium is mined as an ore, the most important being the oxides, pitchblende and uraninite, and the silicate coffinite (Ritcey, 1996). The mined ore is crushed and ground in a mill, then goes through a leaching process, using sulfuric acid, to produce uranium oxide $\left(\mathrm{U}_{3} \mathrm{O}_{8}\right)$ 
(Ritcey, 1996). This form of uranium ore concentrate (UOC), known as yellowcake in Canada, may contain $70-80 \%$ uranium by weight (Rouben, 1998). To produce the actual fuel, the yellowcake must first be reduced to uranium-dioxide $\left(\mathrm{UO}_{2}\right)$ powder, which is then pressed into round ceramic pellets and fired at a high temperature $\left(>1400^{\circ} \mathrm{C}\right)$ (Rouben, 1998). The pellets are then ground to the precise size and shape and encased in metal tubes (usually zircaloy), which are then assembled into fuel bundles (Hore-Lacy, 2003).

Pressurized heavy water reactors (PHWR), of which only the Canada Deuterium Uranium (CANDU) design is in use for commercial power production (Hesketh, 1996), are able to utilize natural uranium fuel, the fuel produced from the above description. However, most other reactor types, such as the Boiling Water Reactors (BWR) used in Sweden, require an enriched form of uranium ${ }^{1}$. For these types of reactors, the yellowcake must first be converted to gaseous uranium hexafluoride $\left(\mathrm{UF}_{6}\right)$, which is then subjected to an enrichment process (Rouben, 1998).

Nuclear energy is produced through the splitting of the uranium isotope $\mathrm{U}^{235}$ in a process known as fission (Lyon and Tutiah, 1984; Wilkinson, 1996; WNA, 2001). Nuclear fission releases a large amount of heat, which is used to produce steam. The steam, in turn, spins large turbines that drive generators to produce electricity (Figure 2). As the $\mathrm{U}^{235}$ is fissioned, some of the non-fissile isotope $\mathrm{U}^{238}$ is converted to fissionable isotopes of plutonium $\left(\mathrm{Pu}^{239}\right.$ and $\mathrm{Pu}^{241}$ ), which also contribute to the energy produced by the reactor (WNA, 2001). Anywhere from one third to half of a reactor's energy output comes from the energy released by plutonium fission (Rouben, 1998; WNA, 2001). As the fuel is burned, there is a gradual

\footnotetext{
${ }^{1}$ Enriched uranium has a higher concentration $\left(3.5-5 \%\right.$ ) of the fissile isotope $\mathrm{U}^{235}$. Naturally occurring uranium only contains $0.72 \% \mathrm{U}^{235}$, with trace amounts $(.0055 \%)$ being $\mathrm{U}^{234}$ and the bulk $(99.27 \%)$ being $\mathrm{U}^{238}$.
} 
depletion of $\mathrm{U}^{235}$, while there is a buildup of fission products and other neutron-absorbers (Rouben, 1998; Hore-Lacy, 2003). After a period of 1-2 years, the concentration of fission products builds up to the point where use of the fuel is no longer practical (WNA, 2004).

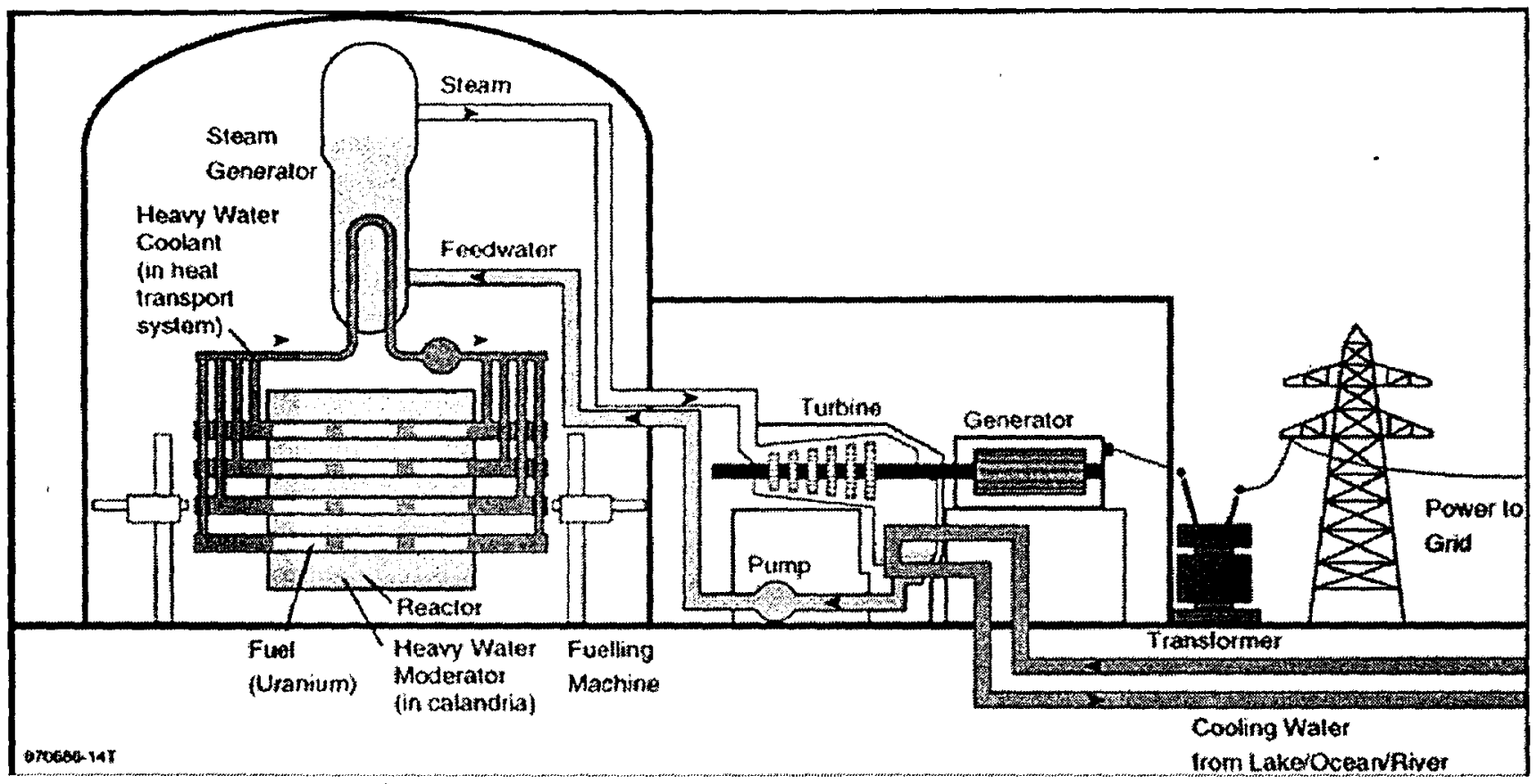

Figure 2. Schematic diagram of a CANDU nuclear reactor (AECL, 2003).

\section{$2.2 \quad$ Nuclear Fuel Waste}

The management and disposal of nuclear fuel wastes is referred to as "back end" of the nuclear fuel cycle (Hore-Lacy, 2003). Nuclear fuel waste comes in the form of the spent fuel assemblies or bundles. Fuel bundles typically weigh around $24 \mathrm{~kg}$, of which $19 \mathrm{~kg}$ is spent uranium $^{2}$ (Lyon and Tutiah, 1984). The spent fuel bundles that are removed from a reactor are extremely hot and highly radioactive ${ }^{3}$. They therefore must first be stored under water to allow them to cool (OLA, 1977). After a number of years, the cooled fuel

2 Information is specific to CANDU fuel bundles, but is comparable to other fuel assemblies.

3 A fresh, spent fuel bundle would emit a lethal radiation dose of about 200,000 rem to an individual standing one meter away. By comparison the recommended dose for the general population is 0.5 rem per year (Ontario Legislative Assembly, 1977). 
assemblies may then be transferred to above ground dry-storage containers, where they can remain for up to fifty years (Rouben, 1998). In many cases the storage facilities for spent nuclear waste are located on site at the nuclear reactor in which it was used (Decamps and Dujacquier, 1997). These storage facilities have been designed to be able to hold all the fuel wastes produced by the reactors up to the end of their lifespan (CEAA, 1998).

Nuclear waste consists of highly radioactive fission by-products, which are capable of releasing ionizing radiation, which in turn is capable of changing the structure of atoms or molecules and is thus highly destructive to living cells (Krauskopf, 1990; Shrader-Frechette, 1993). This, states Shrader-Frechette, is what "accounts for its ability to cause carcinogenic, mutagenic, and teratogenic damage - to induce, respectively, cancer, genetic defects, and birth defects" (pg. 13). It is because of its highly radioactive nature that nuclear fuel wastes must be carefully confined and isolated from human and environmental exposure.

Nuclear waste disposal is based on the principles of concentration and confinement to isolate the radioactive material from the biosphere for periods of time that are in the tens of thousands of years (International Atomic Agency, 1993). In many countries that produce nuclear fuel waste, geological disposal has been accepted as the preferred disposal method (Flynn et al., 1995; Carter, 1987; CEAA; 1998; Decamps and Dujacquier, 1997; Soloway, 2003). Geologic disposal of spent nuclear fuel has been referred to as "reverse mining" (Easterling and Kunreuther, 1995). The waste canisters are placed in a deep underground cavity located in an area whose geology is stable ${ }^{4}$. Once full, the repository will be in-filled using the earth and rock that was dug out (Easterling and Kunreuther, 1995).

\footnotetext{
${ }^{4}$ Examples include salt dome, bedded salt, volcanic tuff, basalt, or granite (Easterling et al., 1995)
} 
All geological disposal concepts utilize a 'multiple barrier' approach to isolate the wastes from the biosphere (Duncan, 2002; IEA, 1993; Soloway, 2003). A multiple barrier system, which consists of engineered and natural or geological barriers, is designed for two purposes: to prevent leakage of radioactive material into the surrounding environment and to provide the necessary time for the radioactivity to decay (Duncan, 2002). Engineered barriers are reported to be significant during the first few hundreds to thousands of years, while the geological barriers become the important factor during the next thousands to tens of thousands of years (IEA, 1993).

Engineered barriers may consist of various components, such as the waste form itself, the waste canisters, the buffer mass and backfill (IAEA, 1993; Soloway, 2003). The waste form or matrix is usually in the form of $\mathrm{UO}_{2}$ for fuel that is being directly disposed of, or borosilicate glass for reprocessed fuel (IAEA, 1993). Waste canisters are designed to completely isolate the waste and typically consist of either corrosion resistant materials such as copper, stainless steel, titanium or ceramics or thick materials such as iron or carbon steel (IAEA, 1993). The functions of the buffer mass and backfill are to "stabilise the repository excavations and the thermo-hydro-mechanical-chemical conditions, and to provide low permeabilities, diffusivities or long-term retardation" (Soloway, 2003, pg. 22).

Certain geological conditions provide a natural barrier to the movement of radionuclides into bi the environment (IAEA, 1993). There are three characteristics that need to be considered when determining the effectiveness of natural barriers: physical isolation and stability; hydrogeological transport processes; and geochemical conditions and processes (IAEA, 1993). Since the transport of radionuclides to the biosphere will mainly be through groundwater movement, it is imperative that geological conditions include the following: 
1) Rocks of very low water content and permeability (e.g., evaporites);

2) Rocks that are not saturated with groundwater (e.g., the unsaturated zone);

3) Rocks with potentially very low contents of mobile water [sic] and very low permeability (e.g., argillaceous rocks);

4) Fractured rocks of low intrinsic permeability, in which radionuclide transport would be controlled by the fracture network (e.g., crystalline rocks in low relief terrains)

(IAEA, 1993, pp. 11-12)

\subsection{Sweden's Nuclear Waste Management Program}

Sweden's first commercial nuclear reactor, Oskarshamn-1 came online in 1972 (Carter, 1987; IAEA, 2003). Prior to the 1970s Sweden had relied mainly on hydro and to a lesser extent, oil for its electricity (WNA, 2004). During the 1960s the Swedish government decided to invest in nuclear power; the shift being prompted mainly by Sweden's large supply of uranium, as a response to protests by environmentalists against the expansion of hydroelectricity, as well as the oil shocks that came during the early 1970s (Carter, 1987). Between 1973 and 1997, the proportion of oil used in energy production fell from $71 \%$ to $29 \%$, while that of nuclear power rose from $1 \%$ to $37 \%$ (IAEA, 2003). Currently, Sweden has eleven nuclear power reactors in operation, producing approximately $50 \%$ of its electricity, with a capacity of 9,459 MWe (IAEA, 2003; WNA, 2004).

The 1979 Three Mile Island accident in the United States prompted a Swedish referendum in the following year regarding the phasing out of nuclear energy (WNA, 2004). Following the referendum, in 1981, Parliament decided to phase out nuclear power by the year 2010 and no

new reactors have since been commissioned. (Carter, 1987; Van den Berg and Damveld, 2000). The first plant to be closed as part of the decommissioning plan was Barseback-1, a 600 MWe reactor that had been in operation since 1975, which was shut down in 1999. A 
second reactor, Barseback-2 was originally slated to close in 2001 but is now scheduled to shut down in May, 2005 (SKI, 2004)

Sweden's nuclear power plants produce approximately $250 \mathrm{t}$ of nuclear waste each year (Ahlström, 1997). To date, the Swedish NWM program has generated an estimated 4000 t of spent nuclear fuel waste (Thegerström et al., 2004). According to the Swedish Nuclear Fuel and Waste Management Company $\left(\mathrm{SKB}^{5}\right)$, an estimated 4500 fuel canisters, equivalent to $9300 \mathrm{t}$ of uranium will eventually require final disposal ${ }^{6}$ (SKB, 2004). Responsibility for the management and disposal of this radioactive waste rests with the nuclear power utilities themselves (Ahlström, 1997; Bjurstrom, 1989; Lidskog and Sundqvist, 2004; Ministry of the Environment, 2003; SKB, 2000). This was the result of the passage of the Stipulation Act in April 1977, which

introduced a new requirement for the charging of new nuclear reactors, inclusive of which was a condition that stipulated that the prospective operators of such reactors must demonstrate that nuclear waste could be disposed of in a safe way.

(Bjarnadóttir and Hilding-Rydevik, 2001, pg. 51).

After the passage of the Stipulation Act, six reactors entered commercial reaction, although there was some contention as to whether the utility had indeed demonstrated that the waste could be disposed of safely. The Stipulation Act also resulted in the creation of SKB, which is owned by Sweden's four nuclear power companies. SKB was commissioned to "develop, plan, design, construct and operate plants and systems for the management and disposal of spent fuel and radioactive waste from the plants” (Bjurstrom, 1989, pg. 139). As such, SKB is said to be the proponent of nuclear waste disposal in Sweden. This includes the disposal of

\footnotetext{
${ }^{5}$ Svensk Kärnbränslehantering $A B$

${ }^{6}$ Based on an operating time of 40 years for the reactors currently in operation (SKB, 20004).
} 
both low and intermediate level waste (LILW) as well high level waste (HLW) (Lidskog and Sundqvist, 2004).

SKB produced three reports dealing with spent fuel management and waste disposal, which became known by their abbreviated names: KBS-1, KBS-2 and KBS- $3^{7}$ (Ahlström, 1997). The preferred method for the disposal of high-level waste is based on the KBS-3 method (Figure 3), which was published in 1983 (Ministry of the Environment, 2003). According to this method, the spent fuel would be placed in copper canisters with solid cast iron inserts, which provides direct isolation of the waste (SKB, 2000). The canisters, which have been given an expected lifetime of over one million years (Carter, 1987), would be embedded in bentonite clay and deposited in the crystalline, granitic bedrock $500 \mathrm{~m}$ below ground (SKB, 2000). The proposed repository would have a capacity of 4500 canisters or $8000 \mathrm{t}$, enough to house all the spent fuel from Sweden's current nuclear activities ${ }^{8}$ (Ahlström, 1997; SKB, 2000).

The KBS-3 method is referred to as a Multi-Barrier Disposal System as it employs a number of separate barriers to ensure that the waste is isolated from the environment:

1) the rock mass, with slow water transport and high capacity for absorption of radionuclides;

2) the near impermeable bentonite clay buffer;

3) the highly corrosion-resistant copper canister; and

4) the low solubility of the spent fuel.

(Bjurstrom, 1989, pg. 141)

${ }^{7}$ KBS stands for Kärnbränslesäkerhet, which translates to "nuclear fuel safety" (SKB, 2000).

8 Based on a 40-year operating life (SKB, 2000). 


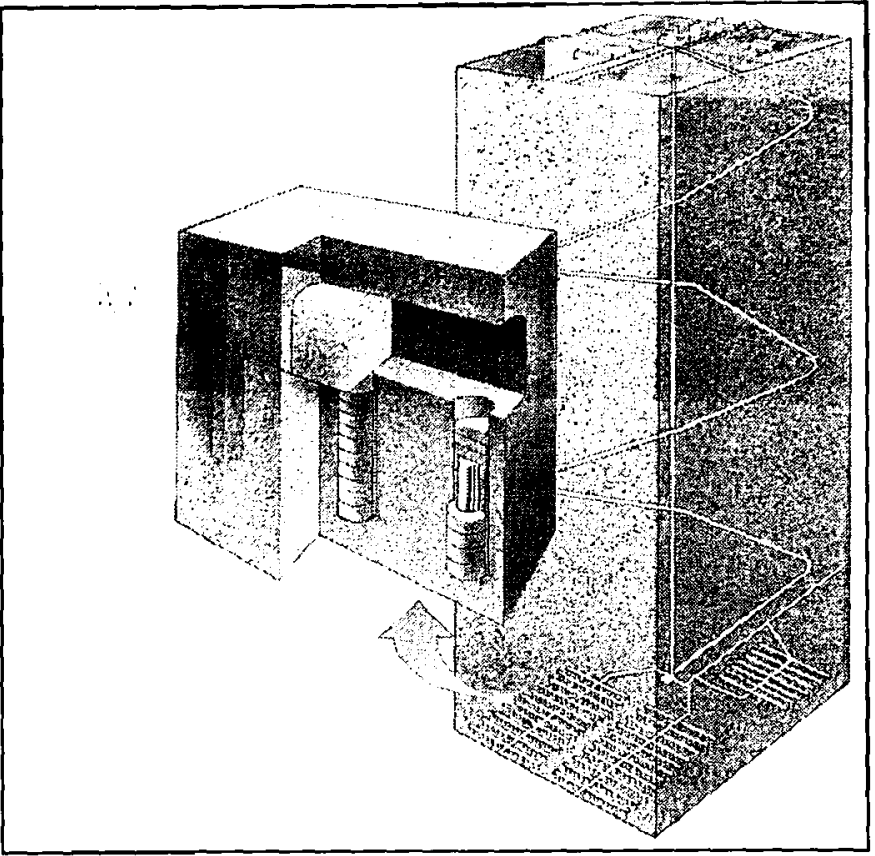

Figure 3. Basic layout of the deep repository based on the KBS-3 Method (SKB, 2004).

In addition to the final repository, the KBS-3 method also entails an interim storage facility, encapsulation plant, and a canister factory (SKB, 2000). The interim storage facility, called CLAB, which is already in place, consists of underground storage pools built in granitic crystalline bedrock (Bjurstrom, 1989; SKB, 2000). It has been in operation since 1985 and has recently increased its capacity from $5,000 \mathrm{t}$ to $8,000 \mathrm{t}$, following the completion of an additional rock cavern (SKB, 2000).

Although the Swedish government and the Swedish Nuclear Power Inspectorate (SKI) have both allowed SKB to proceed with the KBS-3 concept, it still remains to be approved and licensed (Högberg et al., Undated). A number of key issues regarding the KBS-3 method still require further investigation, such as:

- canister design and encapsulation technology;

- design, manufacturing and practical emplacement of the bentonite buffer;

- the adaptation of the repository design to the properties of the host rock; and 
- the scientific basis for understanding of the long time function, e.g., concerning corrosion of the canister, dissolution of the fuel and the migration of radionuclides in the buffer and in fractures of the rock.

(Thegerström et al., 2004, pg. 5)

Upon submission of SKB's application, the government will make a final decision as to which method for waste disposal will be used (Bjarnadóttir and Hilding-Rydevik, 2001). As noted above, there are still a number of scientific and technological issues that need to be addressed, but perhaps the most important aspect of the development of the KBS-3 concept is the siting process (Ahlström, 1997).

During the 1970s and 1980s SKB conducted site-specific investigations to determine whether a repository could be sited safely somewhere in Sweden (Lidskog and Sundqvist, 2004). The investigations involved the drilling of boreholes up to $1000 \mathrm{~m}$ deep in order to take measurements, an activity that drew protests in many of the municipalities (Ahlström, 1997). SKB concluded, based on geological criteria alone, "that there are many places in the Swedish bedrock that provide conditions which are suitable for siting a repository at a depth of about $500 \mathrm{~m}$ " (Ahlström, 1997, pg. 71). As such, SKB argued that other factors such as technology and societal acceptability should be considered of greater importance in the siting process (Lidskog and Sundqvist, 2004).

In 1992, SKB initiated a new siting strategy, which focused on the concept of carrying out feasibility studies in municipalities (Lidskog and Sundqvist, 2004). These feasibility studies addressed a number of concerns including the location of final repository, long-term safety, technical aspects, health, the environment and societal acceptance (Bjarnadóttir and HildingRydevik, 2001). By December 2000, eight studies had been completed (SKB, 2004). Upon 
completion of the feasibility studies, more detailed site investigations were proposed in three of the communities where studies were conducted: Östhammar, Oskarshamn and Tierp (Figure 4). Östhammar and Oskarshamn, both of which already host nuclear facilities, agreed to proceed with site investigations, whereas Tierp rejected further participation (Sjöberg, 2003; Thegerström et al., 2004). The ultimate goal of these site investigations is to obtain a permit to build the deep repository for spent nuclear fuel (Thegerström et al., 2004).

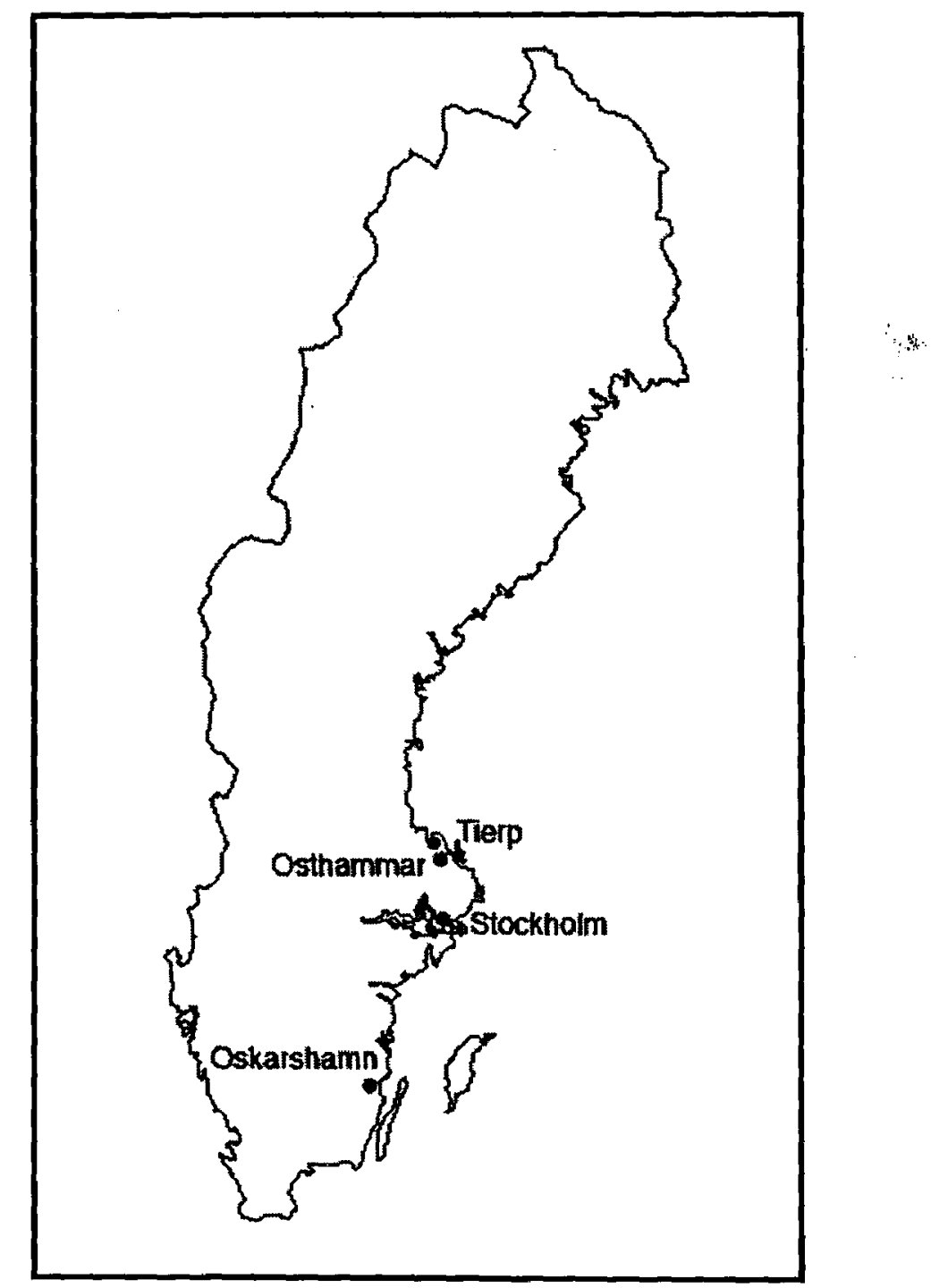

Figure 4. Locations of proposed detailed site investigation municipalities. 
At present, site investigations for a deep geological repository, which include surface-based investigations using deep boreholes, are being conducted at two candidate sites: Forsmark in the municipality of Östhammar and Simpevarp/Laxemar in the municipality of Oskarshamn (SKB, 2004). According to SKB's RD\&D Programme 2004, other developments in the nuclear fuel program include: pilot- and full-scale tests of parts of the KBS-3 method, which are currently being undertaken at the Canister Laboratory and the Äspo Hard Rock Laboratory; as well as the development of the encapsulating technology and the design of an encapsulation plant (SKB, 2004). SKB plans to submit its license application for siting and construction, which will include the chosen site for the deep repository, in 2008 (SKB, 2004). Initial operation is expected to commence around 2015 (SKB, 2000).

\subsection{Canada's Nuclear Waste Management Program}

Canada began using nuclear power to generate electricity in 1962, when the 25 MWe Nuclear Power Demonstration (NPD) plant in Rolphton, Ontario was connected to the energy grid (Boulton, 1978). As of April 2004, Canada had seventeen nuclear reactors in operation, generating approximately $12-15 \%$ of the country's electricity, with a capacity of 12000 MWe (IAEA, 2003; WNA, 2004). Fifteen of these reactors are located in the province of

Ontario, where nuclear energy accounts for $40 \%$ of the province's electricity (IAEA, 2003). The only other provinces that utilize nuclear power are Quebec and New Brunswick, each having one operating reactor (CNA, 2004; IAEA, 2003; WNA, 2004).

Canada's nuclear power program produces approximately 85,000 spent fuel bundles per year (CEAA, 1998). At the end of 2001, Canada had accumulated a total of 1,564,147 spent fuel bundles, containing 30,000 t of uranium (CNSC, 2003). It is estimated that by the year 2073, 
10 million spent fuel bundles will have been produced (CEAA, 1998). Spent fuel bundles are currently stored in reactor pools located on site at the nuclear power plants in which they were used, and are thus the responsibility of the utility. The proponent of nuclear waste disposal in Canada, however, is Atomic Energy of Canada Limited (AECL). AECL, a nuclear technology and services company, is a Crown corporation that was established by the Government of Canada in 1952, with the mandate of developing peaceful uses of nuclear energy (AECL, 1989).

The concept of deep geological disposal of nuclear fuel wastes was first considered by a committee of AECL in 1972 (NWMO, 2003). In 1974, the Department of Energy, Mines and Resources was asked to review the concept of waste disposal in geologic formations and to recommend suitable formations (Boulton, 1978). The province of Ontario held its first public review of its nuclear waste policy in 1975, conducted by the Ontario Royal Commission on Electrical Power Planning (van den Berg and Damveld, 2000). In 1978, the Governments of Canada and Ontario directed AECL to develop the concept of deep geological disposal of nuclear fuel wastes (van den Berg and Damveld, 2000). This stemmed from a report produced by a panel of experts that was established by the Ministry of Energy, Mining and Resources in 1977, known as the Hare Report ${ }^{9}$ (van den Berg and Damveld, 2000). On the types of rock suitable for geologic disposal, the panel concluded:

We feel that several different kinds of rock could profitably be studied but that resources ought not to be spread too thinly. We suggest that primary effort be given to the crystalline rocks of plutonic origin (i.e., deep in the earth), but that careful attention be paid to the work of other scientists in other countries on different rock types.

\footnotetext{
${ }^{9}$ Named after the panel's chairman, Dr. Kenneth Hare.
} 
As the main producer of nuclear power, the panel also recommended that Ontario be the location of the first nuclear waste disposal facility (Aikin, 1977).

In the early 1980s, AECL began conducting test drillings in northern Ontario, near the town of Massey and the Sagamok First Nations (van den Berg and Damveld, 2000). The drillings drew considerable protest, prompting a referendum in Massey. With referendum results showing $88 \%$ of the residents opposed the test drillings, AECL withdrew (van den Berg and Damveld, 2000). Similar protests in five other communities prompted AECL to halt specific site studies and focus on '"generic' research and the development of a 'concept' for deep disposal" (van den Berg and Damveld, 2000, pg. 33).

AECL's concept for the geological disposal of nuclear fuel waste, which does not require perpetual care, is described as follows:

- the waste form is either used CANDU fuel or the solidified high-level waste from reprocessing;

- the waste form is sealed in a container designed to last at least 500 years and possibly much longer;

- the containers of waste are emplaced in rooms in a disposal vault or in boreholes drilled from the rooms;

- the disposal rooms are nominally 500 to $1000 \mathrm{~m}$ below the surface;

- the geological medium is plutonic rock of the Canadian Shield;

- each container of waste is surrounded by a buffer;

- each room is sealed with backfill and other vault seals; and

- all tunnels, shafts, and exploration boreholes are ultimately sealed in such a way that the disposal facility would be passively safe; that is, long-term safety would not depend on institutional controls.

(AECL, 1994, pg. 5) 
After ten years of research, the Federal Minister of Energy, Mines and Resources referred AECL's concept, along with other nuclear fuel waste management issues, for public review (CEAA, 1998). In 1989, the Federal Minister of the Environment appointed an independent eight-member panel, headed by Blair Seaborn, to conduct an environmental assessment and public hearing on AECL's concept (CEAA, 1998; van den Berg and Damveld, 2000). In addition, the Panel created a Scientific Research Group (SRG) to review the technical aspects of AECL's concept (van den Berg and Damveld 2000).

al In 1994, AECL submitted an Environmental Impact Statement (EIS) for its concept, which was made available for public review for a period of five months (CEAA, 1998; van den Berg and Damveld, 2000). Between 1996 and 1997, public hearings were conducted on a wide variety of topics relating to the management of nuclear fuel waste. The public hearings were conducted in the three provinces that produced nuclear fuel wastes (New Brunswick, Quebec and Ontario). In addition, the Panel was "asked to include Manitoba, where an AECL research facility is located, and Saskatchewan, as requested by the provincial government” (CEAA, 1998, pp. 6-7). In 1998, the Seaborn Panel submitted its report regarding the Nuclear Fuel Waste Management and Disposal Concept (CEAA, 1998). The Panel's main finding was that the disposal concept lacked broad social acceptability and thus, could not be adopted as Canada's nuclear waste management strategy (CEAA, 1998).

The government's response to the Seaborn Panel's report was to introduce legislation as the "preferred mechanism...to fulfill its policy objectives of federal oversight" (NRCAN, 2002). It became clear that the government's new policy was to ensure public confidence that the next steps for the long-term management of nuclear fuel waste would be carried out in their best interests (Brown, 2003). 
On April 25, 2001, the Minister of Natural Resources introduced Bill C-27 in the House of Commons, which dealt with the long-term management of nuclear fuel waste (IAEA, 2003; NRCAN, 2002). The Nuclear Fuel Waste Act (NFWA) received royal assent on June 13, 2002 and came into force on November 15, 2002 (IAEA, 2003; NRCAN, 2002).

The purpose of the NFWA "is to provide a framework to enable the Governor in Council to make, from the proposals of the waste management organization, a decision on the management of nuclear fuel waste that is based on a comprehensive, integrated and economically sound approach for Canada" (Dept. of Justice Canada, 2002). The requirements set out by the $N F W A$ are as follows:

- that nuclear utilities form a Waste Management Organization (WMO) as a separate legal entity;

- that the WMO report regularly to the Government of Canada and provide recommendations on the long-term management of nuclear fuel waste;

- that utilities and Atomic Energy Canada Limited (AECL) establish a trust fund to finance long-term nuclear fuel waste management activities; and

- that the government review and approve key activities of the WMO

(NRCAN, 2002)

The Nuclear Waste Management Organization (NWMO) that was subsequently created consists of the Ontario Power Generation Inc. (formerly Ontario Hydro), the New Brunswick Power Corporation, Hydro-Québec, and AECL (NWMO, 2003). The NWMO is required to assess three different methods to manage nuclear fuel waste: deep geological disposal in the Canadian Shield; storage at nuclear reactor sites; and centralized storage, either above or below ground, and to make a recommendation as to which method should be adopted 
(NWMO, 2003). The purpose of the NWMO is "to develop collaboratively with Canadians a management approach for the long-term care of Canada's used nuclear fuel that is socially acceptable, technically sound, environmentally responsible and economically feasible" (NWMO, 2003).

As mandated by the NWFA, the NWMO is to consider only used nuclear fuel, and not other types of radioactive waste (NWMO, 2003). The NWMO is required to submit the results of its study, along with its final recommendation to the Government by November 2005 (NWMO, 2003). Once submitted, the Lieutenant-Governor, on the recommendation of the Minister of Natural Resources, is to select one of the approaches to implement (NWMO, 2003). The Lieutenant-Governor is not obligated to select the approach recommended by the NWMO, while the NWMO will be responsible for implementing the selected approach.

\subsection{The Nuclear Waste Siting Dilemma}

A siting dilemma is defined as a situation in which "an 'authority' deems it in the best interest of society to build a facility such as an incinerator, but opponents living near the proposed site thwart the plan" (Easterling and Kunreuther, 1995, pg. vii). Such is the case with nuclear waste facilities, which have been protested against in every single nuclear country (Shrader-Frechette, 1993). In the United States, for instance, numerous siting attempts and several billions of dollars - the most of any nuclear nation - have been spent trying to create disposal facilities for radioactive and other hazardous wastes (Freudenburg, 
2004; Gerrard, 1994; Rabe, 1994). Despite this, however, nearly every attempt to site a nuclear waste repository in the US has failed ${ }^{10}$ (Freudenburg, 2004).

A similar situation exists in Canada, where between 1978 and 1995 approximately $\$ 538$ million was spent on research and development on the concept of deep geological disposal of high-level nuclear waste (HLW) (Auditor General, 1997). Despite the time and resources that have been spent studying the geological disposal option, the Canadian government has yet to decide whether it will indeed be the method used to manage its spent fuel, much less located a site for a geological repository. Canada's approximately 85,000 spent fuel bundles that are being produced every year are currently being held in either wet or dry storage facilities located at the nuclear generating stations (CNSC, 2003). It has been suggested that a permanent disposal solution, that does not rely on institutional controls is needed in order to "permanently protect human health and the natural environment from the potentially harmful effects of nuclear fuel wastes, and to minimize the burden on future generations" (CEAA, 1998, pg. 18). As noted in Chapter 1, the lack of a permanent solution to the nuclear waste problem may have serious implications for the future of nuclear power production. Although the federal government has vowed continued support of nuclear energy, it is likely to encounter greater opposition in the absence of a permanent disposal solution (CEAA, 1998).

\subsubsection{Public Opposition - Not-In-My-Back-Yard}

Public opposition to nuclear waste facilities has been dubbed by many as the NIMBY (NotIn-My-Back-Yard) syndrome, an "intense and often adamant resistance by the local population" (Kraft and Clary, 1993, pg. 96). Although it is considered one of the most

\footnotetext{
${ }^{10}$ The one exception is a New Mexico facility, which handles nuclear wastes from military uses (Freudenburg, 2004).
} 
significant barriers to long-term nuclear waste management (Rabe, 1994), the phenomenon is not unique to nuclear waste facilities; many unpopular facilities such as landfills, prisons, affordable housing projects, mental health hospitals and even daycares have been opposed as the result of NIMBY (Inhaber, 1998). The NIMBY response has even surfaced in proposed theme parks in Virginia and California (Munton, 1996). Although commonly believed to be a relatively recent trend, the NIMBY response has in fact been documented as early as the mid-1950s (Inhaber, 1991).

NIMBYism is often considered an irrational response by a poorly informed local public (Kraft and Clary, 1993). When related to hazardous waste facilities, it is also perceived by some as a tactic used by "chemophobes and environmental fanatics" as a means of disrupting the industrialized economy (Rabe, 1994). This motive suggests the premise that if all communities took that same stance, the government will be unable to site the facility anywhere. This would force industry to reduce waste production, through, for instance, a reduction in nuclear power consumption (Inhaber, 1991).

On the other hand, Rabe (1994) argues that NIMBY is simply a realistic local response to poorly designed national and sub-national policies. Furthermore, as Bingham (1984) argues, NIMBY is a rational response by a local community to a proposed facility that would make that community worse off. Others have also dismissed the claim that the selfish attitudes of local communities prevent the attainment of societal goals by preventing the siting of facilities, which provide an important social benefit (Lake, 1993). Lake argues that such facilities are needed more by capital than by society, and by a state striving to reproduce the capital-labor relationship, and that therefore, local protectionism characterized as NIMBY represents a barrier not to societal goals but to the goals of capital (Lake, 1993). The siting 
of a hazardous waste incinerator, for instance, is only one of the possible solutions to the problem of industrial hazardous waste production. Lake argues that rather than restructure production in order to produce less waste, which would concentrate the costs on industry, decision makers have often opted instead to try and site a waste facility, which concentrates the costs on the local community (Lake, 1993).

\subsubsection{Roots of Public Opposition}

\section{$\underline{\text { Risk Perception }}$}

Opposition to nuclear waste facilities has largely been attributed to the public's perceptions of the risks such facilities present (Kuhn, 1998; Slovic et al., 1991). According to Kuhn (1998), the public perception is that the risks associated with a nuclear waste facility are "unacceptably high and threatening" (pg. 2) and would result in an inequitable burden on the host community. This is despite the fact that a nuclear waste repository is likely to reduce the "aggregate radiation risk faced by current and future generations" (Easterling, 1992, pg. 444). Although experts in the nuclear industry generally regard the risks from a nuclear waste facility to be relatively small, the general public tends to view these risks as being significantly greater (Carter, 1987). For instance, a survey conducted by Kunreuther et al. (1988) found that respondents rated the risks from a potential nuclear waste repository, such as the probability of wastes being leached into groundwater or transportation accidents, as being significantly higher than other sources.

Risk perception research reveals a number of possible reasons for the incongruity between the perceptions of experts and the general public regarding nuclear facilities. Slovic (1987) found that the risks associated with nuclear power are viewed by people as being "unknown, 
dread, uncontrollable, inequitable, catastrophic, and likely to affect future generations" (pg. 163). Another study by Slovic et al. (1991) found that the four words most frequently associated with the phrase "underground nuclear waste repository" were dangerous, danger, death and pollution. One of the reasons put forth to explain this inherent fear of all things related to nuclear is that since radiation cannot be detected by the five senses, it creates an ambiguity of harm, which has been shown to produce greater levels of stress in people than well-understood levels of harm (Freudenburg, 2004). The author adds that since radioactivity is not empirical, there is a lack of controllability over the hazard, resulting in the public having to rely on sophisticated equipment and the people that run them (Freudenburg, 2004, pg. 164).

Unfavourable media coverage is also partly responsible for the public's perceptions regarding the risks associated with nuclear facilities (Kasperson et al., 1988; Kunreuther et al., 1996; Slovic, 1991; Summers and Hine, 1997). According to Kasperson et al. (1988) the media tend to focus on rare or dramatic risk events, making it easier to recollect previous accidents or failures. Major accidents like those at Three Mile Island (TMI) in 1979 and in Chernobyl in 1986, for instance, have certainly increased public opposition to nuclear power (Shrader-Frechette, 1993). Ahearne (1987) reports that between 1976 and 1986 there was a steady increase in survey respondents who were opposed to building more nuclear power plants in the United States, with marked increases after both TMI (to 40\%) and Chernobyl (to $73 \%)$.

The public's perception of the risks associated with nuclear facilities can also be explained by the association people make between nuclear power and nuclear weapons (Slovic, 1987). 
The bombings of Hiroshima and Nagasaki during World War II demonstrated to the world the destructive power of nuclear energy. According to Smith (1988):

Nuclear energy was conceived in secrecy, born in war, and first revealed to the world in horror. No matter how much proponents try to separate the peaceful from the weapons atom, the connection is firmly embedded in the minds of the public.

(Smith, 1988, pg. 62)

\section{Lack of Public Trust}

The public's perception of risks is said to be shaped by the amount of trust placed in those responsible for managing the risk (Sjöberg and Drottz-Sjöberg, 1997). It has been proven time and again that the level of trust the public has for nuclear authorities and government officials has broken down considerably over the past few decades (Carter, 1987; Dunlap et al., 1993; Flynn et al., 1992; Easterling and Kunreuther, 1995; Gerrard, 1994; Hine et al., 1997; Slovic et al., 1991). In the United States, this lack of trust has been attributed to the military origins of nuclear technology (Shrader-Frechette, 1993). Shrader-Frechette reports that the Manhattan Project ${ }^{11}$ has resulted in nuclear decision-making that is fraught with secrecy, centralization and technocracy. In fact, the 1946 Atomic Energy Act contained a provision that allowed the nuclear sub-government ${ }^{12}$ to keep atomic secrets for national security purposes (Rosa and Freudenburg, 1993). It would be decades before public interest groups would force new legislation that required greater public disclosure of the US's nuclear endeavours (Rosa and Freudenburg, 1993). For instance, Shrader-Frechette (1993) reports that in 1986 the U.S. Department of Energy (DOE) released 19,000 pages of previously

\footnotetext{
${ }^{11}$ The Manhattan Project was the United States' secret project to develop atomic bombs during World War II.

${ }^{12}$ Rosa and Freudenburg (1993) describe the nuclear sub-government as "a closely knit group consisting of the nuclear industry, federal agencies overseeing the technology, and key congressional committees" (pg. 33).
} 
classified information regarding operations at the nuclear weapons facility in Hanford, Washington during the 1940s and 1950s. Among some of the revelations contained in the documents were radiological experiments performed on local people, either without their knowledge or permission (Shrader-Frechette, 1993). Rosa and Freudenburg (1993) add that issues regarding nuclear wastes were particularly kept secret, more so than any other nuclear management issue.

In the United States, the public's distrust of nuclear authorities, namely the Department of Energy (DOE) has further increased in light of the mishandling of nuclear wastes from the country's nuclear weapons facilities, such as Hanford (Flynn et al., 1992; Slovic et al., 1991). According to Slovic et al. (1991) over $\$ 150$ billion will be required to clean up the leakage from the country's military weapons facilities. Flynn et al. (1992) add that there is "a pervasive distrust of both Congress and DOE, built up during three decades of ill-fated attempts to dictate a solution" (pg. 42). The issue of public trust is well summarized by Jacob (1990):

Stories in the mass media about reactor accidents, nuclear waste mismanagement, cost overruns, and the alleged federal cover-up of radiological disasters created public distrust, which threatened the continued promotion of nuclear power by the federal government.

The lack of trust in government authorities and the nuclear industry translates into a continued distrust of their assessments of nuclear waste facilities as having low risk (Duncan, 2002). This poses a significant problem in nuclear waste siting efforts, particularly given that "once lost, public trust and confidence in governmental institutions are difficult to rebuild" (Kraft and Clary, 1993, pg. 111). To compound the problem, the public is said to lack trust 
even in the concept of nuclear waste disposal itself and "fully expects the system to fail, and the waste, while still hazardous, to reconnect with the biosphere" (Duncan, 2002, pg. 75). This is confirmed by Slovic et al. (1991); a survey conducted by the authors revealed that respondents did not believe that a repository would prevent the release of radionuclides into the environment. Duncan (2002) adds that while experts are quick to point out scientific risk probabilities (e.g., a less than a $10^{-6}$ per year chance that an individual will suffer deleterious health effects from radioactive material released from a repository) these expressions mean little to the general public (Duncan, 2002).

\section{Lack of Public Participation}

It is now a widely held belief that nuclear waste management involves far more than just solving technical problems (Flynn et al., 1992; Freudenburg, 2004; Kraft, 2000; Murdock et al., 1983). In fact, the most critical issues surrounding nuclear waste management are said to be those relating to social science (Murdock et al., 1983). Unfortunately, these issues historically have not received the attention that they merited. Rather, nuclear waste disposal policy was grounded heavily in technical research, such as risk assessments regarding potential releases of nuclear contamination and the consequences of exposure to contamination (Kraft, 2000). Kraft adds that although social, economic and political factors are considered, they typically have a limited impact on policy decisions, which are influenced most by technical analyses (Kraft, 2000).

That technical concerns have always been given greater consideration than social issues is a sentiment repeatedly found in the current research literature (Dunlap et al., 1993; Easterling and Kunreuther, 1995; Flynn et al., 1992; Freudenburg, 2004; Kraft, 2000; Munton, 1996). 
According to Flynn et al. (1992), "[a]lthough large amounts of money have been poured into the scientific and engineering aspects of high-level radioactive waste disposal, virtually nothing has been done to actively enlist the public in the siting process or to collaborate with the public in forging a solution" (pg. 42). To make matters worse, when authorities deal with the public, "[t]here is a tendency to use very top-down technocratic language, to view individuals in communities as pests, and rather than wanting to engage in meaningful dialogue, to want to dismiss and get through the public resolution process as quickly as possible" (Rabe, 1996).

One of the most critical social issues surrounding nuclear waste management is how to involve local parties in the siting process (Murdock et al., 1983). Historically, the prevailing method of siting hazardous waste facilities has been a "top-down" approach known as Decide-Announce-Defend (DAD) (Flynn et al., 1995; Munton, 1996; Rabe, 1994). Rabe (1996) describes this approach as one in which a governmental body makes a decision on the siting of a facility, then tries to impose that facility on a particular community, with little or no prior consultation. The government then "mount[s] whatever effort seems necessary to defend and secure approval of, or at least acquiescence to, this choice" (Munton, 1996, pg. 11). During the 1970 s and 1980 s it became apparent that this approach was repeatedly ending in failure, leading to a NIMBY response (Munton, 1996; Rabe, 2000). Munton (1996) attributes this partly to the undemocratic process by which that site was decided upon: "A vital part of the opposition to planned facilities results from what is perceived to be an attack on basic democratic principles" (pg. 2).

The consequence of not having adequate public consultation is evident in the following example from the Environmental Assessment (EA) of the Canadian nuclear fuel waste 
management and disposal concept (Kuhn and Murphy, 2001). The authors state that the current setting of Terms of Reference ${ }^{13}$ in the EA process provides inadequate opportunity for public consultation. They report that "while proponents have an opportunity to be involved in the negotiations, the public, including NGOs, do not have a way to participate legitimately until after the terms of reference are released and scoping is underway" (Kuhn and Murphy, 2002, pg. 262). As a result, NGOs and other public groups resorted to threats and letter writing campaigns to government officials. The authors conclude that conflicts between the proponents, government agencies, regulators, NGOs and the public could have been avoided had the setting of the terms of reference been done in a "spirit of cooperation and compromise" (pg. 263).

It is clear that the lack of public participation in siting issues can only lead to "confrontation and stalemate" (Munton, 1996, pg. 11). If nations are to implement a successful nuclear waste policy, they will need to design "decision making processes that can provide for the level and kind of public participation capable of producing consensus on socially acceptable risk" (Kraft, 2000, pg. 208).

\subsubsection{Overcoming Opposition}

It is important to point out at this point that not all siting efforts have resulted in failure. Although far from being commonplace, examples can be found of controversial facilities overcoming public opposition and being successfully sited (Gerrard, 1995; Castle and Munton, 1996; Rabe, 1994). Perhaps the most cited case of a hazardous waste facility gaining local acceptance is the Swan Hills Special Waste Treatment Centre in Swan Hills,

\footnotetext{
${ }^{13}$ The Terms of Reference for an EA define the proposed project and its boundaries
} 
Alberta (Gerrard, 1995; Rabe, 1994). Following two failed private attempts to locate a hazardous waste facility in the late 1970s, Alberta's provincial government decided to take over the siting process and in 1984 , selected Swan Hills with the support of $79 \%$ of local voters $^{14}$ (Gerrard, 1995). One of the factors attributable for the success in Swan Hills is the Alberta government's decision to make the siting process voluntary (Gerrard, 1995). In 1984, all the municipalities in Alberta were asked if they wished to be considered for a hazardous waste facility. Communities had to volunteer before any studies were to be conducted (Gerrard, 1995; Castle and Munton, 1996; Rabe, 1994). Perhaps the most important factor in the success at Swan Hills is the province's use of various mechanisms to involve the public in the siting process (Rabe, 1994). These included the creation of liaison committees, one of which held over 120 meetings throughout the province, providing such information as the types of siting criteria that may be used (Rabe, 1994).

Another example of a successful siting effort occurred in Greensboro, North Carolina during the mid-1980s with the siting of the ECOFLO hazardous waste storage, treatment and disposal facility (Rabe, 1994). Much like the Swan Hills case, the siting process was made voluntary, and incorporated extensive public involvement, early in the process (Rabe, 1994). It differed, however, in that the process did not involve the entire state and was not headed by a governmental authority. Rather, the process was headed by Tom Barbee, a Greensboro resident who had experience as a waste transporter (Rabe, 1994). Barbee was able to reach a siting agreement with the community through his commitment to an open planning process. He held numerous meetings with various organizations and individuals, earning the

${ }^{14} 69 \%$ of eligible voters participated (Gerrard, 1995). 
community's trust by providing whatever information was requested and constantly seeking input regarding the facility's design as well as the planning process itself (Rabe, 1994).

The preceding examples highlight the favourable effects that effective public participation can have on the siting process. One of the explanations for this is that "broad-based public participation offers a measure of control over the process of risk characterization" (Short and Rosa, 2004, pg. 148). This sense of control, add the authors, leads to decreased fear over phenomena and greater willingness to accept risks and uncertainty (Short and Rosa, 2004). In addition, it has been reported that success is more likely when a proponent accommodates the local concerns of the community in an honest and meaningful way (Flynn et al., 1992).

It is widely agreed upon in the current literature that the public needs to be involved at all steps of the siting process, including the definition and identification of the problem as well as the decision making regarding any proposed solutions (Short and Rosa, 2004). It is particularly important to involve the public early in the process. According to Treichel (2000) honest risk communication and transparency must take place prior to starting any siting process. For the public to even consider accepting a nuclear waste facility, for instance, they must first agree that the facility is both necessary (not taking action would be costly or risky) and appropriate (the proposed facility is the best that can be done and is a significant improvement over the status quo) (Treichel, 2000). In addition to occurring early in the decision-making process, public participation, in order to be effective, must be extensive (Rabe, 1994). In both the Swan Hills and Greensboro cases, the proponents attempted to reach as many groups and individuals as possible, both to inform and gain as much input as possible. 
In discussions regarding public participation, one often encounters the term 'stakeholder'. A stakeholder can be defined as "a person or other actor with special concern and interest in an issue, and may be considered to be concerned either on the basis of self-report or on the basis of observed activities" (Sjöberg, 2003, pg. 740). Past efforts at public participation meant the involvement of stakeholders in decision-making processes (Short and Rosa, 2004). However, it has been reported that stakeholders do not necessarily represent the views of the general public as they tend to be more extreme (Sjöberg, 2003). Sjöberg (2003) adds that stakeholders opposed to a proposed facility tend to be more outspoken, despite the fact that they tend to comprise a relatively smaller group. It is thus important to engage not just the stakeholders, but also the "affected parties who may not recognize their stake in risks to be characterized" (Short and Rosa, 2004, pg. 148). Sjöberg (2003) goes further by suggesting that when communicating with the public regarding risks, it should be done with the general public, as opposed to giving priority to stakeholders. Indeed, providing all affected parties with an equal opportunity to participate and shape the decision-making process has been shown to arrive at a consensus within the local community (Short and Rosa, 2004).

The other major factor in the successes at both the Swan Hills and Greensboro cases was the voluntary nature of the siting process. Voluntary processes are more likely to gain local support than traditional top-down processes as they consider a number of potential sites, rather than a single one chosen by the proponent (Castle and Munton, 1996). Although most communities will not accept a facility, "the more communities that are considered, the higher the overall likelihood of one siting success" (Castle and Munton, 1996, pg. 74). Gerrard (1995) also states that using a voluntary approach "elicits a far different psychological 
response" (pg. 109) in local communities. According to Gerrard (1995), there are three specific advantages to the voluntary approach:

1. It decreases intrusion - by making the risk voluntary it reduces the perception of risk

2. It draws out those communities with cultures that will accept facilities

3. It tends to lead to payment of the full social costs of a facility, since the hidden subsidies of preemption are eliminated

(Gerrard, 1995, pg. 132)

The idea of compensation has also been used to try to overcome public opposition to the siting of hazardous waste facilities. Three specific purposes of compensation have been identified:

1. to induce localities to accept facilities;

2. to make victims whole; and

3. to increase economic efficiency by internalizing the external costs of facilities.

(Gerrard, 1995)

According to Kunreuther (1996), compensation ensures that the benefits associated with hosting a facility are greater than maintaining the status quo.

The effectiveness of compensation is somewhat debatable. Kunreuther (1996) reports that support for facilities in several communities in the United States doubled when "some form of compensation was introduced into the picture" (pg. 345). However, Gerrard (1995) argues that compensation only works when the "community does not believe the proposed facility poses an undue hazard" (pg. 127). Thus, there is the danger of compensation being perceived as a bribe (Gerrard, 1995, Inhaber, 1991). On the other hand, Inhaber (1991) adds that incentives ${ }^{15}$ differ from bribes in that bribes are given and accepted in secret. Thus, the

\footnotetext{
${ }^{15}$ In the research literature, the terms "compensation" and "incentives" are used interchangeably.
} 
success of incentives depends on how they are offered or presented (Inhaber, 1991). For instance, the United States Environmental Protection Agency (EPA) offers incentives in the form of grants that allow citizen groups to retain experts of their choice (Inhaber, 1991).

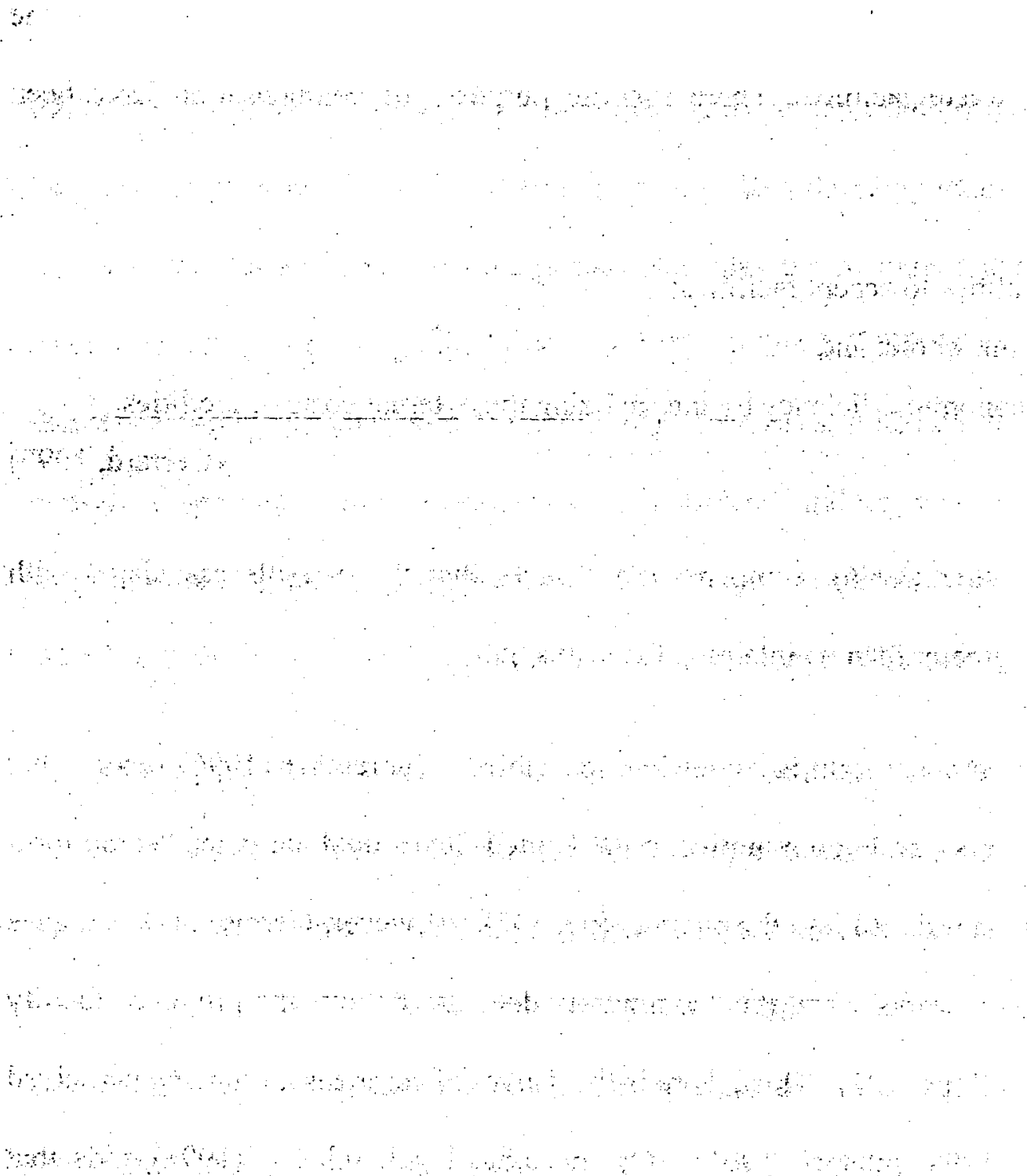




\section{Methodology}

\subsection{Research Design}

The purpose of this study is to determine the significance of public engagement in a successful nuclear waste management strategy. The main instrument employed in this study is a primary and secondary document review.

This study is conducted in three parts. The first part of the study consists of a qualitative review of the nuclear waste management programs of Sweden and Canada. The progress and current status of each country's nuclear waste management program is documented. In addition, significant milestones throughout the programs are identified and compared in terms of the amount of time it took to reach each milestone.

The next part of the study involves the identification and comparison of specific aspects of public engagement during comparable periods in each country's nuclear waste management program or siting process. In the Swedish case, the period is marked by the implementation of the new siting strategy in 1992. In the Canadian case, the period to be studied is during the Panel Review of the Nuclear Fuel Waste Management and Disposal Concept (1989-1998). These specific periods have been chosen as they represent opportunities for the proponents in each country to engage the public in the nuclear waste issue. It should be noted that in the Canadian case, the time period is closed, whereas in Sweden, it is considered open as the siting strategy is still currently being implemented and engagement activities are ongoing. The author has declined to include in the analysis, the current work of the NWMO in the 
Canadian case as it represents a marked departure from the engagement activities conducted during the Panel Review. One of the goals of this study is to determine any shortcomings of the public engagement aspect of the Canadian nuclear waste management program. Although the NWMO has committed to engaging the public in the nuclear waste issue at the present time, their efforts do not reflect what had taken place during the Panel Review, and thus have not be taken into account. In addition, while the disposal option during the Panel Review was a deep geological repository, the NWMO is currently considering other strategies besides deep geological disposal.

For this part of the study, a quantitative comparison of the following aspects is employed:

1. Access to information

2. Level of contact

3. Financial resources devoted to public engagement

Lastly, in order to gauge the effectiveness of each country's public engagement activities, a comparison is made of the public awareness of the nuclear waste issue in each country, as well as public support for each country's nuclear waste management program. This is accomplished by examining surveys of public attitudes towards nuclear waste and nuclear waste management in each country.

\subsection{Data Collection}

The data used for this study have been compiled from a number of sources. The first part of the study relies on documents from a variety of primary and secondary sources. These 
include reports from each country's nuclear authorities, government publications, journal articles, and direct correspondence with various organizations, authorities and/or individuals involved in the nuclear waste siting process.

The data used for the second part of the study was obtained mainly from primary sources. For the Swedish case, the main source of information is the Swedish Nuclear Fuel and Waste Management Co. (SKB). Relevant documents include:

- Eight Feasibility Study Final Reports (one from each of the municipalities of Storuman, Malå, Östhammar, Nyköping, Oskarshamn, Tierp, Hultsfred and Älvkarleby);

- Four Site Investigation Annual Reports (two each from the municipalities of Östhammar and Oskarshamn); and

- the following reports published by SKB: Extended Consultations According to the Environmental Code, Activities 2003 and Activities 2004.

In addition, data were obtained through direct correspondence with individuals at SKB. It should be noted at this point that although much of the data regarding the Swedish case was available in English, there were some documents that were only available in Swedish. For those documents not available in English, the services of a Swedish translator were enlisted.

For the Canadian case, the primary source of data consists of documentation of the Panel Review of the Nuclear Waste Management and Disposal Concept, which include the following:

- the Report of the Nuclear Fuel Waste Management and Disposal Concept Environmental Assessment Panel;

- transcripts of the scoping meetings; and

- transcripts of the public hearing proceedings. 
Data were also obtained through direct correspondence with individuals at the Canadian Environmental Assessment Agency and Atomic Energy Canada Ltd.

The data used to make a comparison of the effectiveness of each country's public engagement activities were obtained from the following surveys:

- Canadian Attitudes Toward Nuclear Energy - Focus Canada Omnibus Summary Report, conducted by Environics Research Group in 2003 for the Canadian Nuclear Association

- Public Attitudes to Nuclear Waste and the NWMO Project, conducted by Navigator in 2003 for the Nuclear Waste Management Organization

- Europeans and Radioactive Waste, conducted by INRA (Europe) in 2001 for the European Commission's Directorate General for Energy \& Transport

- The 2005 annual opinion survey regarding the deep repository conducted by the polling firm Temo for $\mathrm{SKB}^{16}$.

\subsection{Data Analysis}

For the first part of the study, primary and secondary source documents are reviewed in order to construct a timeline, which outlines the development of each country's nuclear waste management program. From this timeline, significant milestones are identified and compared in terms of the amount of time it took each country to reach each milestone.

For the next part of the study, primary source documents are reviewed in order to obtain data regarding the specific measures of public engagement noted above.

\section{Access to Information}

For the purpose of this study, public access to information is measured according to the number of materials pertaining to the nuclear waste management program and/or siting

\footnotetext{
${ }^{16}$ Full document available in Swedish only. Pertinent survey results were provided in English by Sara Björklund, Coordinator Social Science of SKB.
} 
process that have been published in each country. It is also measured according to the number of people that have visited each country's nuclear research facilities. Since nuclear research facilities may be regarded as direct sources of information, the number of visits to such facilities is used as an indirect measure of public access to information.

\section{Level of Contact}

For this study, level of contact with the public is measured on the basis of the number of "contact events" conducted by the proponents ${ }^{17}$, during the aforementioned time periods. This provides a measure of the degree of issue penetration among the general population that the proponent has achieved. Contact events may include meetings, seminars, hearings or other formal and informal gatherings conducted by the proponent or in which the proponent participated in order to engage the public in the nuclear waste issue.

Financial Resources Devoted to Public Engagement

Another measure of how well the public is engaged in the nuclear waste issue is the amount of financial resources committed to public engagement. For the public to have meaningful participation in the nuclear waste issue, sufficient funding must be provided. Monetary support is required for such things as the publication of information materials, retaining personnel dedicated to providing public information and to provide the public with access to outside experts to review information that are of a more technical nature.

17 For this part of the analysis, the proponent in the Canadian case is taken to be the Environmental Assessment Panel. Although the actual proponent of the disposal concept is AECL, all public involvement initiatives were conducted by the Environmental Assessment Panel, as prescribed by the federal Environmental Assessment and Review Process Guidelines Order.

In the Swedish case, the proponent is the Swedish Nuclear Fuel and Waste Management Co. (SKB). 
In the final part of the study, surveys of public attitudes towards nuclear waste and nuclear waste management in Sweden and Canada are examined to determine the level of public awareness regarding the nuclear waste issue as well as the amount of support for each country's respective nuclear waste management programs. Public awareness and support are used to gauge the effectiveness of each country's public engagement activities.

\subsection{Assumptions and Limitations}

It is imperative to note that in conducting this study a number of assumptions had to be made. Although both Sweden and Canada have been engaged in the nuclear waste issue for a similar length of time, there are quite a few inherent differences between the two countries that must be kept in mind.

First, one must consider the geography and population characteristics of each country. Sweden's mean population from 1992, when the new siting strategy was implemented, to the present is estimated at approximately 8.8 million. With a land area measuring $410,934 \mathrm{~km}^{2}$, Sweden has a population density of roughly 22 persons per $\mathrm{km}^{2}$ (SCB Statistics Sweden, 2005). Canada's mean population during the Panel Review (1989-1998) is estimated at approximately 28.8 million, roughly three times that of Sweden. With a land area that is roughly twenty-two times larger than Sweden's at 9,220,970 $\mathrm{km}^{2}$, Canada has a much lower population density at 3.5 persons per $\mathrm{km}^{2}$ (Statistics Canada, 2005).

Furthermore, whereas most of Sweden's geography has been identified as being suitable for a geologic repository $\left(\mathrm{SKB}, 2004^{\mathrm{a}}\right)$, in Canada the suitable area is limited to the area containing plutonic rock known as the Canadian Shield (AECL, 1994). This could certainly have an influence on the implementation of a nuclear waste strategy, particularly if the 
ultimate goal of that strategy is the siting of a geological repository, which is the case in both Sweden and Canada.

Reliance on nuclear energy for electricity production is another factor that must be taken into account. In Sweden, nuclear energy accounts for approximately half of the country's electricity production, while in Canada the proportion is much less at $12 \%$ (WNA, 2004). In addition, national support for nuclear energy is significantly greater in Sweden than it is in Canada (Table 2). Moreover, in Canada, there are only three provinces that utilize nuclear energy (Ontario, Quebec and New Brunswick); in fact, most of Canada's nuclear reactors are clustered in the province of Ontario. In Sweden, on the other hand, nuclear energy provides electricity nationwide. This could partially account for the fact that the nuclear waste issue is much more at the forefront in Sweden than it is in Canada.

\section{Table 2. Support for nuclear energy in Sweden and Canada ${ }^{18}$.}

\begin{tabular}{|l|c|c|}
\hline & Support Nuclear Energy & Oppose Nuclear Energy \\
\hline Sweden & $83 \%$ & $13 \%$ \\
\hline Canada & $50 \%$ & $40 \%$ \\
\hline
\end{tabular}

Source: Temo, 2005; Environics, 2003

For the purpose of this study, it is assumed that the aforementioned differences between the two countries are of less significance in the successful implementation of a nuclear waste management program than the degree of public involvement.

\footnotetext{
${ }^{18}$ When asked about their personal view of nuclear power in Sweden, $13 \%$ of Swedish respondents wanted nuclear power phased out, $4 \%$ did not answer. $19 \%$ wanted to build new and more reactors, $30 \%$ wanted to continue nuclear power production and replace existing ones when they have reached the end of their operating lives, and 34\% felt nuclear power should be used until present reactors had to be closed of safety or cost grounds.
}

The Environics survey asked whether respondents strongly support, somewhat support, somewhat oppose or strongly oppose the use of nuclear energy to produce electricity in Canada. 17\% of respondents strongly support nuclear power, $33 \%$ somewhat support it, $17 \%$ were somewhat opposed, and $23 \%$ were strongly opposed. 
The reader need also be warned of the limitations of this study. It should be noted that a fundamental difference exists between the stages at which the nuclear waste management programs in each country are being compared. While the public participation program in Sweden deals with the actual process of siting a geological repository, in the Canadian case, the public participation aspects being considered in this study occurred during a review of the geological disposal concept, which, at the time, was being considered without an actual site in mind.

In the second part of this study, three aspects of each country's public engagement programs $\therefore$ are compared. With respect to the first two aspects (access to information and level of contact), the reader need be advised that the study does not analyse the content of the proponents' message. Rather, the analysis attempts to determine the level of outreach of each proponent by quantifying physical aspects of their public participation programs, such as the number of information materials they've published, and the number of times they made contact with the public.

With respect to the analysis of the level of contact, the lack of attendance figures during the Panel Review in the Canadian case also poses a limitation. For this analysis, the most effective measure of contact between proponents and the public would certainly have been a record of the actual number of individuals with whom contact was made. Although the data were available in the Swedish case, unfortunately, attendance records during the open houses, scoping meetings and public hearings for the Canadian Panel Review were not kept. As such, it was decided that a comparison of the number of events at which public contact was made would suffice. 
For the analysis of the amount of funding for public participation activities, it should be noted only the amount provided by the proponents in each country have been considered.

Another limitation relates to the final part of this study, namely the analysis of survey results in each country to determine public support for their respective nuclear waste management programs. As the surveys in each country were performed by different polling firms and for different purposes, the questions asked were not identical. In the Swedish case, the question posed by the polling firm specifically asked whether or not one would support a deep repository if it were to be found in one's municipality. In the Canadian case, however, the question posed was more general in nature, asking simply how confident one was that the nuclear authorities had a good system in place to deal with nuclear waste. Although the two surveys did not explicitly ask the same question, the author feels that they both convey the same sentiment with regards to the level of public support for their respective country's nuclear waste management programs. While the Canadian process has not yet reached a siting stage, a high level of confidence in the nuclear authorities is needed if acceptance of a geological repository is to be attained. 


\section{Results}

\subsection{Progress and Current Status of NWM Programs}

Timelines highlighting the major developments in the nuclear waste management programs in Sweden and Canada over the past thirty years, are shown in Figures 5 and 6, respectively.

- From these timelines, it is evident that both Sweden and Canada began studying the nuclear waste issue roughly at the same, during the early 1970s. In Sweden, the first official study to be conducted on the issue of nuclear waste disposal was the so-called AKA Investigation, which was conducted from 1973-1976 (Bjarnadóttir and Hilding-Rydevik, 2001). In Canada, the concept of deep geological disposal of nuclear fuel wastes was first considered by AECL in 1972 (NWMO, 2003). The direction of research was similar in both countries, with Sweden conducting test drillings between 1977-1985 (SKB, 2004), and Canada doing s: likewise during the early 1980s (van den Berg and Damveld, 2000). The test drillings conducted in both countries drew considerable protest from the municipalities involved.

Despite the protests, a significant milestone was reached in the Swedish nuclear waste management program when the Government approved the KBS-3 method for spent fuel waste management and disposal in 1983. From there on, the Swedish nuclear waste management program progressed in what has been called a stepwise development (Ahlström, 1997). During the early 1980s construction began on an interim storage facility for spent nuclear fuel, CLAB, which began operating in 1985 (Johansson, 2003, SKB, 2000). This was followed by the completion of a repository for low- and intermediate-level waste (LILW) in 1988 (Bjurstrom, 1989). The facility, known as SFR-1, is located near the 


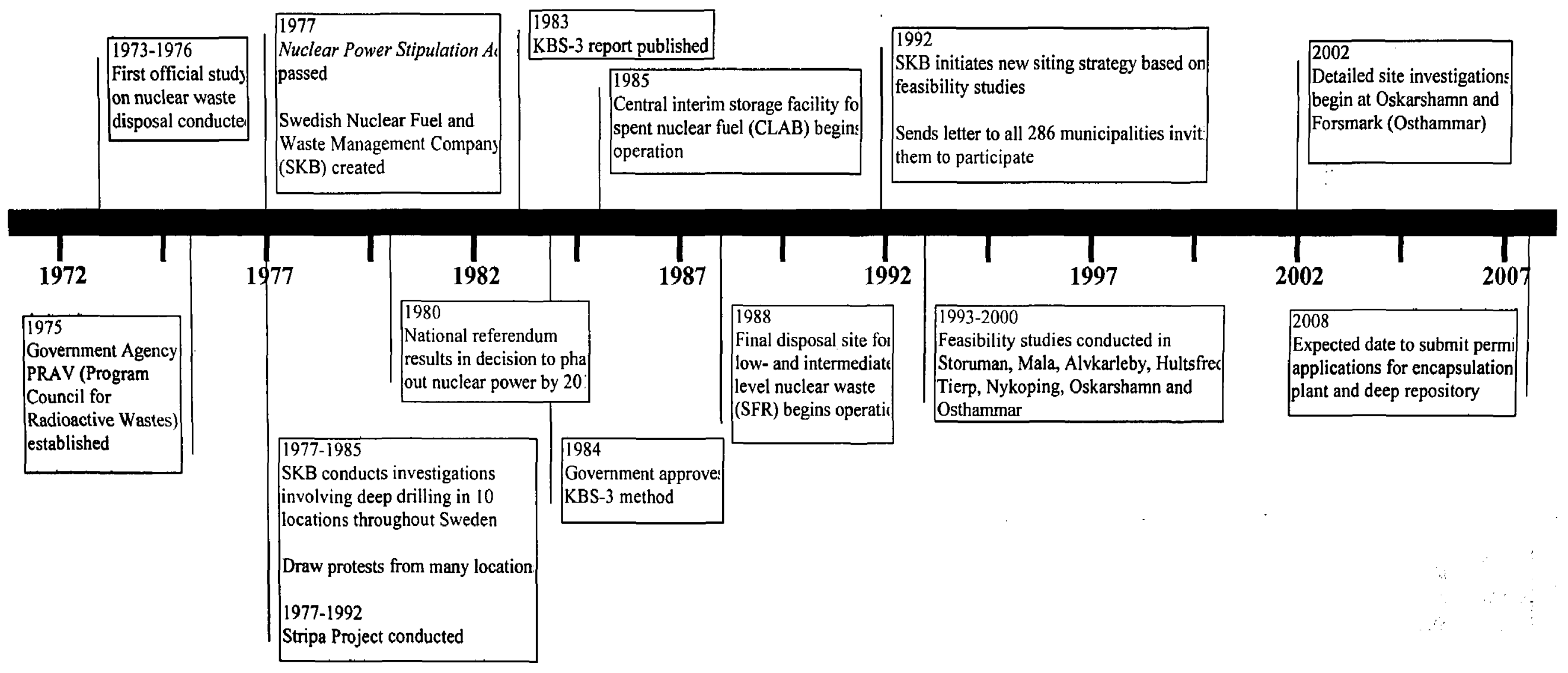

Figure 5. Major developments in Sweden's nuclear waste management program. 


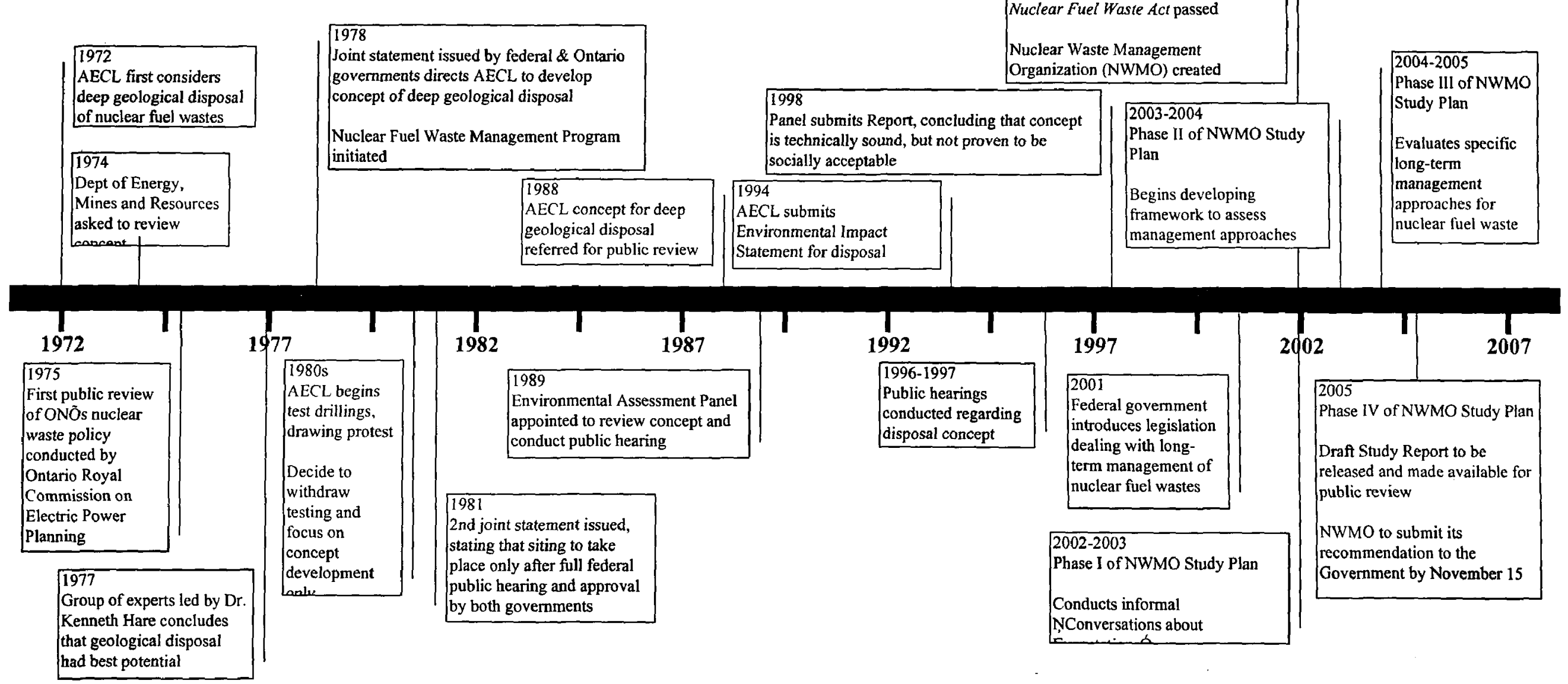

Figure 6. Major developments in Canada's nuclear waste management program 
Forsmark nuclear plant, $50 \mathrm{~m}$ below the Baltic Sea, and has a capacity of $60,000 \mathrm{~m} 3$ (Decamps and Dujacquier, 1997).

Canada's Nuclear Fuel Waste Management Program was officially initiated in 1978 with the issuance of the joint statement by the federal and Ontario governments directing AECL to develop the concept of deep geological disposal (van den Berg and Damveld, 2000). The directive was based on the results of a study conducted by a panel of experts led by Dr. Kenneth Hare, which stated that geological disposal of nuclear fuel wastes had the best potential (CEAA, 1998). In 1981, the federal and Ontario governments issued another joint statement, establishing that siting of a disposal facility would only take place "after a full federal public hearing and approval of the concept by both governments" (CEAA, 1998, pg. 6). This most likely was a response to the numerous protests that were prompted by AECL's test drillings, and resulted in AECL abandoning further drillings and focusing only on the development of a concept (van den Berg and Damveld, 2000). Thus, by the time the Canadian concept was referred for a public review in 1987, the Swedish government had already approved the KBS-3 concept, constructed an interim storage facility, and nearly completed a repository for LILW.

In Sweden, the formal siting process was initiated in 1992, based on the concept of carrying out feasibility studies in municipalities (Lidskog and Sundqvist, 2004). The feasibility studies would be carried out on a voluntary basis and, in response to the protests over the test drillings, would be based on existing data (Ahlström, 1997). Over the next eight years, eight feasibility studies would be completed. Around this time, the Public Review of the Nuclear Fuel Waste Management and Disposal Concept was being conducted in Canada. Open houses were hosted in the spring of 1990 to "increase public awareness of the review process, 
the proposal under review and the opportunities to participate" (CEAA, 1998, pg. 7). In the fall of the same year, scoping meetings were held in 14 communities to develop Environmental Impact Statement (EIS) guidelines. AECL submitted its EIS in 1994, which was followed by another series of open houses in the fall of 1994 and winter of 1995 (CEAA, 1998). The public hearings were held between 1996-1997. The Panel submitted its recommendations to the federal government in 1998, concluding that while the concept had been proven to be sound from a technical perspective, it had not been proven to be socially acceptable (CEAA, 1998). Thus, on the basis of the concept not likely being accepted by a community, the Panel concluded that the concept as described by AECL's EIS should not be adopted and was thus not approved by the Government.

In 2001, the Canadian federal government introduced legislation dealing with the long-term management of nuclear fuel waste. The Nuclear Fuel Waste Act came into force in November 2002, creating the Nuclear Waste Management Organization (NWMO). In Sweden, three municipalities that had participated in the feasibility studies were selected to undergo more detailed site investigations: Östhammar, Oskarshamn and Tierp (Thegerström et al., 2004). While a referendum in Tierp led to that municipality declining further participation, detailed site investigations began in Östhammar and Oskarshamn in 2002, and are still ongoing (SKB, 2004). Once site investigations have been completed, one site will be chosen for the final geological repository. SKB plans to submit its license application for the siting and construction of the deep repository in 2008 , and expects to commence operation by 2015 (SKB, 2000; SKB, 2004).

In Canada, the NWMO is considering two other methods for managing Canada's used nuclear fuel waste. In addition to geological disposal, they are studying continued storage at 
reactor sites and centralized storage (NWMO, 2003). The NWMO has identified four phases in its study plan (NWMO, 2005):

1. In Phase 1, the NWMO conducts informal conversations with "a range of individual Canadians, communities of interest and key stakeholders to introduce itself and to better understand the views and needs of Canadians at large".

2. During Phase 2, the NWMO conducts engagement and dialogue activities to determine "what is required in a long-term management approach for nuclear fuel waste" and "to solicit input, advice and direction in the development...[of] a preliminary framework for analyzing and assessing the alternative management approaches".

3. In Phase 3 of its study plan, the NWMO evaluates specific long-term management approaches for nuclear fuel waste, while continuing to conduct "dialogue activities to review and discuss NWMO's assessment of the long-term management approaches, and to suggest changes and revisions to assist in the development of a recommendation".

4. In the final phase, the NWMO plans to release a Draft Study Report, which includes their recommendation, to be made available for public review and comment before submitting a final recommendation to the Government, the deadline for which is November 15.

With the Canadian government expected to approve a method presumably in 2006, it can be said that the Canadian nuclear waste management program has been set back approximately twenty years when compared to the Swedish case, where a disposal method was approved back in 1983. 


\subsection{Measures of Public Engagement}

\subsubsection{Access to Information}

Public access to information is measured on the basis of how much information is made available to the public by the proponents in each country. A comparison has been made of $5:$ the number of information materials that have been published in each country regarding its nuclear waste management program and/or siting process. Tables 3 and 4 show the total number of information materials that have been published in Sweden and Canada, respectively. It should be noted that for the purpose of this study, only materials that were intended to inform the public about each country's respective nuclear waste management program have been included. Technical reports or other papers intended mainly for the scientific community have not been included.

Table 3. Number of information materials published or released by SKB regarding the Swedish nuclear waste management program.

\begin{tabular}{|c|c|}
\hline Type of Material & Number of Materials Published / Released \\
\hline $\begin{aligned} \text { News Releases } \\
\bullet \\
\text { - English } \\
{ }^{19} \\
\text { Swedish }\end{aligned}$ & $\begin{array}{l}11 \\
37\end{array}$ \\
\hline Brochures & 25 \\
\hline Magazines $^{21}$ & 11 \\
\hline Other $^{22}$ & 43 \\
\hline TOTAL & 127 \\
\hline
\end{tabular}

${ }^{19}$ English news releases posted on SKB's website from 2004 to the present.

${ }^{20}$ Swedish news releases posted on SKB's website from 1999 to the present.

${ }^{21}$ Two different editions of the magazine Lagerbladet are published quarterly in Oskarshamn and Östhammar, where site investigations are currently being undertaken.

${ }^{22}$ Includes all non-technical information material that has been made available to the general public via SKB's publications page. 
Table 4. Number of information materials published or released regarding the Canadian Panel Review of the Nuclear Fuel Waste Management and Disposal Concept.

\begin{tabular}{|l|c|}
\hline Type of Material & Number of Materials Published / Released \\
\hline News Releases $^{23}$ & 51 \\
\hline News Bulletins $^{24}$ & 6 \\
\hline Other $^{25}$ & 3 \\
\hline TOTAL & $\mathbf{6 0}$ \\
\hline
\end{tabular}

It is evident from the preceding tables that in Sweden, there has been more than twice the number of materials published or released to the general public regarding the nuclear waste management program than during the Panel Review in Canada. Thus, the general public in Sweden can be said to have greater access to information regarding the nuclear waste management program than did the Canadian public during the Panel Review of the disposal concept.

For the purpose of this study, public access to information is also measured indirectly via the number of visits to each country's nuclear research facilities. Tables 5 and 6 show the number of visits to the Äspo Hard Rock Laboratory (HRL) operated by SKB in Sweden and the Underground Research Laboratory (URL) operated by AECL in Canada, respectively.

${ }^{23}$ Source: personal correspondence with Kristine Northey, CEAA.

${ }^{24} \mathrm{Six}$ issues of the news bulletin Dialogue were published between 1990-1994

25 FEARO announced the availability of three documents in December, 1989 (An Issue Paper on the Management of nuclear Fuel Wastes prepared by the Lura Group, A Review of Various Approaches Being Undertaken by Industrialized Nations for the Management and Disposal of High-Level Nuclear Waste prepared by Acres International, and Managing Canada's Nuclear Fuel Wastes published by AECL) which were intended to assist participants to prepare for scoping meetings. 
Table 5. Annual number of visitors to SKB's Äspo Hard Rock Laboratory (HRL) between 1994-2004.

\begin{tabular}{|c|c|}
\hline Year & \# of Visitors \\
\hline 1994 & 3,179 \\
\hline 1995 & 3,100 \\
\hline 1996 & 4,539 \\
\hline 1997 & 4,898 \\
\hline 1998 & 6,931 \\
\hline 1999 & 12,211 \\
\hline 2000 & 12,760 \\
\hline 2001 & 12,348 \\
\hline 2002 & 8,969 \\
\hline 2003 & 10,440 \\
\hline 2004 & 10,093 \\
\hline TOTAL & $\mathbf{8 9 , 4 6 8}$ \\
\hline AVERAGE PER YEAR & 8,133 \\
\hline
\end{tabular}

Source: Personal correspondence with Sten Kjellman, SKB

Table 6. Annual number of visitors to AECL's Underground Research Laboratory (URL) between 1991-2001.

\begin{tabular}{|c|c|c|c|}
\hline Year & \# of Public Tours & \# of Technical Visits & Total \\
\hline 1991 & 457 & 557 & 1014 \\
\hline 1992 & 490 & 502 & 992 \\
\hline 1993 & 749 & 434 & 1183 \\
\hline 1994 & 830 & 500 & 1330 \\
\hline 1995 & 983 & 399 & 1382 \\
\hline 1996 & 1579 & 348 & 1927 \\
\hline 1997 & 511 & 269 & 780 \\
\hline 1998 & 106 & 393 & 499 \\
\hline 1999 & 124 & 133 & 257 \\
\hline 2000 & 149 & 135 & 284 \\
\hline $2001^{26}$ & 0 & 375 & 375 \\
\hline TOTAL & $\mathbf{5 9 7 8}$ & $\mathbf{3 6 7 0}$ & $\mathbf{9 6 4 8}$ \\
\hline AVERAGE PER YEAR & 598 & 367 & 965 \\
\hline
\end{tabular}

Source: Personal correspondence with Cathy Bennet, AECL Communications

26 AECL stopped conducting public tours of its facilities after the September 11, 2001 terrorist attacks on the World Trade Center buildings (personal correspondence with Cathy Bennett of AECL). 
It is clear that there have been a far greater number of visitors to the Äspo HRL than there have been to AECL's URL. The total number of visitors to the Äspo HRL during the period 1994-2004 was 89,468 , while the total number of visitors to AECL's URL during the period 1991-2001 was nearly ten times fewer at $9,648^{27}$. The average number of visitors to the Äspo HRL during any given year was 8,133 , compared to 965 to AECL's URL, nearly a tenfold difference.

A graphical comparison of the number of visitors to each facility can be found in Figure 7. It is of interest to note that in the Swedish case, there was a near doubling of the number of visitors to the Äspo HRL to 12,211 in 1999 from 6,931 the preceding year. This coincides with the peak in the feasibility studies, six of which were being conducted at the time. It appears to be a clear sign that SKB had increased its efforts to educate and inform municipalities and the general public about its nuclear waste management program and the related research being conducted at its facilities.

In Canada, a similar peak can be found in 1996, where the number of public tours to AECL's URL was 1,579 , up from 983 the year before. This increase may be attributed to the public hearings for the Panel Review of the Disposal Concept, which began in the same year. Although this increase appears significant, it is the author's opinion that AECL could have made better use of the public hearings as an opportunity to inform more of the general public about its proposed disposal concept and the research it was conducting.

27 This includes both public tours and technical visits to AECL's URL. The corresponding figures in the Swedish case do not distinguish between public and technical visits, but rather represent the total number of visitors to the facility. 


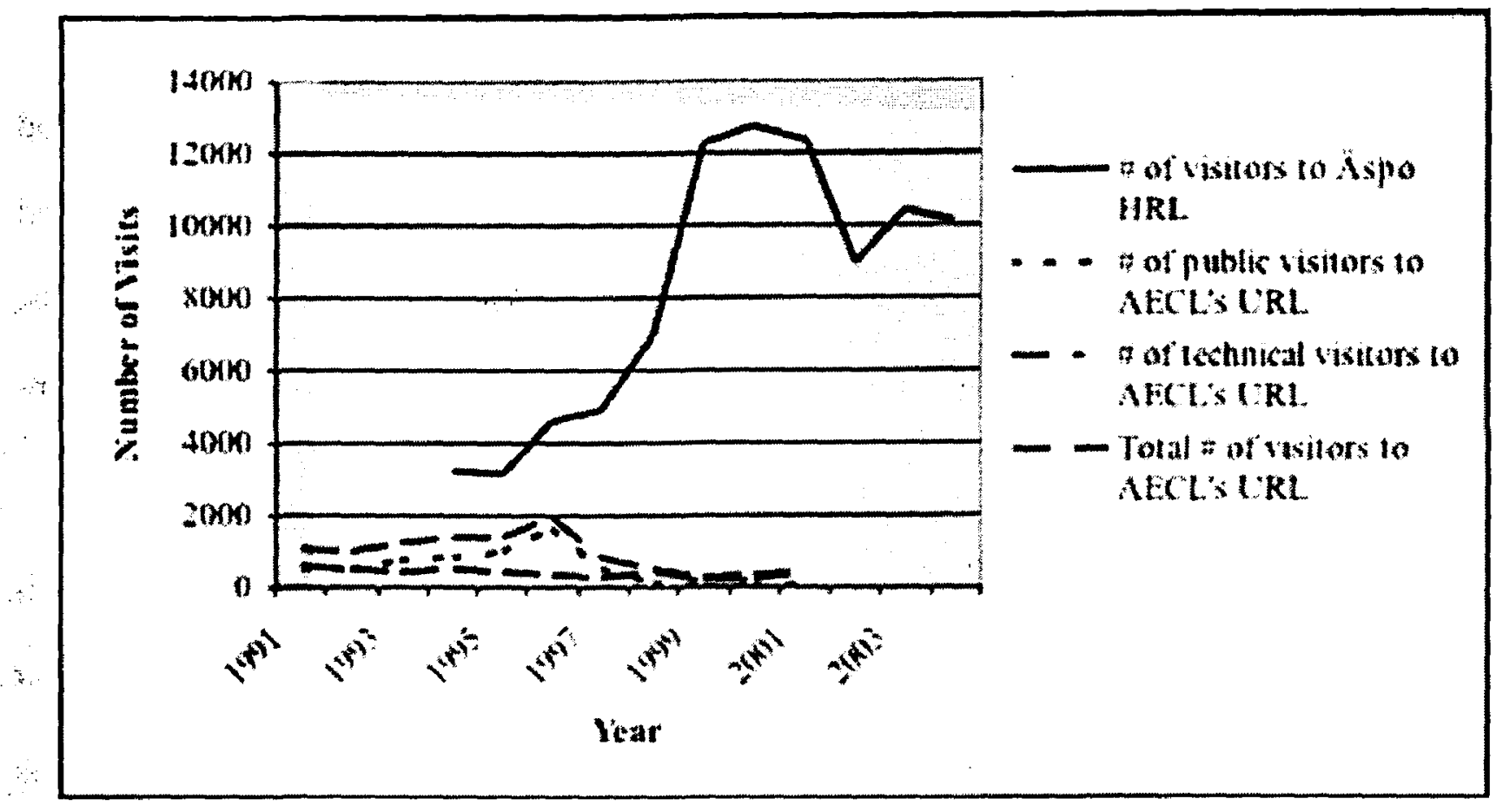

Figure 7. Graphical comparison of the number of visits to the Äspo HRL and AECL's URL.

\subsubsection{Level of Contact}

The level of contact that the proponents in each country have made with the public is measured on the basis of the number of events that the proponents have either conducted or participated in regarding the nuclear waste issue. As mentioned in the previous chapter, the ideal way of measuring level of contact would be to determine the number of individuals with whom contact was made. However, due to a lack of the availability of this exact information, the author believes that a comparison of the number of events at which contact with the public was made would provide sufficient evidence as to the level of contact that was made.

Table 7 presents a summary of the events at which SKB made direct personal contact with the public since the implementation of the new siting strategy in 1992. As previously 
mentioned, in 1992 SKB sent a letter to each of Sweden's 286 municipalities, inviting them to participate in a feasibility study. In the years following, eight municipalities would agree to conduct a feasibility study. SKB published a Feasibility Study: Final Report for each municipality in which a feasibility study was conducted. Included in the Appendices of each report is a list of dialogue and information activities conducted by SKB in the municipality during the feasibility study. After the completion of the feasibility studies, two municipalities were selected to undergo more detailed site investigations: Oskarshamn and Östhammar. During the course of these site investigations, early and extended consultations have been held regarding an encapsulation plant for spent fuel and the final repository (SKB, 2003).

For the purpose of this research, contact events are considered to be any event either hosted by SKB or in which SKB participated, including the following:

- Public, information, and/or consultation meetings

- Public lectures;

- Seminars;

- Debates;

- School presentations;

- Fairs;

- Visits by SKB's exhibition trailer;

- Visits by the spent fuel transport ship, M/S Sigyn;

- Open houses at SKB's site offices; and

- Study trips/excursions ${ }^{28}$.

For simplification purposes, the author has refrained from presenting a breakdown of each type of contact event. Instead, only the total number of contact events made at each feasibility study municipality is reported.

\footnotetext{
${ }^{28}$ Not including visits to nuclear facilities, as these have already been accounted for in the previous section.
} 
Table 7. Number of events at which SKB has made contact with the public since 1992.

\begin{tabular}{|c|c|}
\hline Type of Contact Event & \# of Contact Events \\
\hline $\begin{array}{c}\text { Contact with Feasibility Study Municipalities } \\
\qquad \text { Storuman } \\
\text { - Malä } \\
\text { - Östhammar } \\
\text { - Nyköping } \\
\text { - Oskarshamn } \\
\text { - Tierp } \\
\text { - Hultsfred } \\
\end{array}$ & $\begin{array}{c}34 \\
56 \\
135 \\
212 \\
78 \\
128 \\
56 \\
80 \\
\end{array}$ \\
\hline 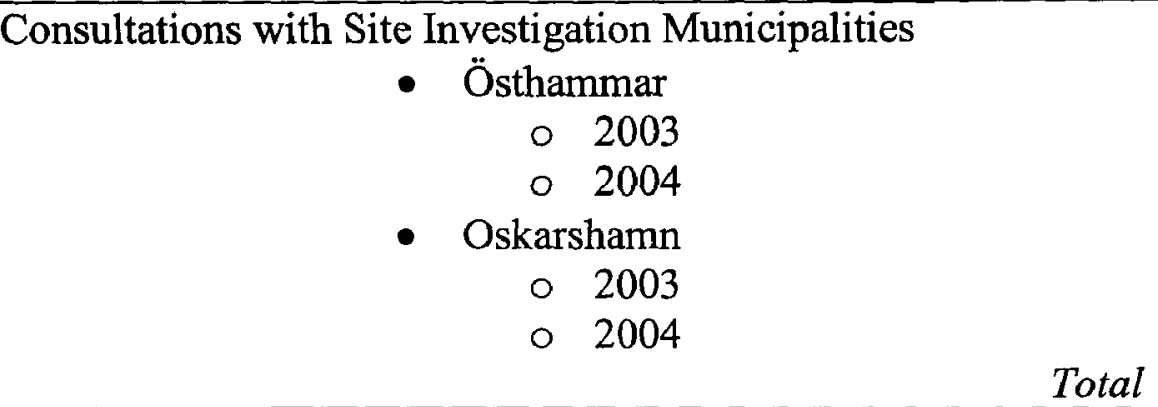 & $\begin{array}{l}6 \\
4 \\
7 \\
6\end{array}$ \\
\hline Other & 5 \\
\hline TOTAL & 807 \\
\hline
\end{tabular}

SKB has also hosted other contact events aside from those at the feasibility and site investigation municipalities, which are listed in Table 7 under the category Other. One of these is a consultation meeting with various national authorities and government agencies regarding the scope of the upcoming EIA for the encapsulation plant and repository. In addition, SKB has held four Annual SKB Days (2000-2003), where "politicians, decisionmakers and representatives of the press and the academic and business communities... discussed nuclear waste issues in Sweden and the rest of Europe" (SKB, 2003, pg. 24). The SKB Day held in 2003 more than was attended by more than two hundred delegates (SKB, 2003). 
In total, there have been 807 events at which SKB has engaged the public regarding its nuclear waste disposal strategy since the new siting strategy was implemented in 1992 . The greatest number of contact events occurred in the municipality of Nyköping, where between May 1995 and August 2000, there were 212 events at which SKB made contact with the public. It is interesting to note that the fewest number of contact events took place at Storuman and Malä, with thirty-four and fifty-six contact events, respectively. These two municipalities, which were the first two to volunteer to have a feasibility study conducted, would later hold referendums in which the citizens opted to withdraw from further investigations. It appears that with subsequent municipalities, SKB increased its efforts to engage and maintain a dialogue with the public, as is evidenced in the municipality of Nyköping, as mentioned above, and the municipalities of Östhammar and Tierp, which had 135 and 128 contact events, respectively.

A summary of the events at which contact was made with the public by the EA Panel during the Panel Review of the Nuclear Fuel Waste Management and Disposal Concept is presented in Table 8. There were four types of events hosted by the EA Panel during which the public was engaged and informed regarding the review of the disposal concept:

- Open houses, which were "designed to increase public awareness of the review process, the proposal under review and the opportunities to participate" (CEAA, 1998, pg. 7);

- Scoping meetings, at which the public could provide input in identifying the scope of the proposed project and the factors that need to be considered during the environmental assessment (CEAA, 2003);

- Public hearings; and

- A workshop on Aboriginal issues. 
Table 8. Number of events at which the EA Panel made contact with the public during the Panel Review of the Nuclear Fuel Waste Management and Disposal Concept.

\begin{tabular}{|c|c|}
\hline Type of Contact Event & \# of Contact Events \\
\hline $\begin{aligned} & \text { Open Houses } \\
& \bullet \text { New Brunswick } \\
& \bullet \text { Quebec } \\
& \bullet \text { Ontario } \\
& \bullet \text { Manitoba } \\
& \bullet \text { Saskatchewan } \\
&\end{aligned}$ & $\begin{array}{c}7 \\
9 \\
17 \\
3 \\
6\end{array}$ \\
\hline $\begin{aligned} \text { Scoping Meetings } \\
\bullet \\
\text { - New Brunswick } \\
\text { - Ontario } \\
\text { - Manitoba } \\
\text { - Saskatchewan }\end{aligned}$ & $\begin{array}{l}4 \\
4 \\
8 \\
1 \\
3\end{array}$ \\
\hline $\begin{aligned} \text { Public Hearings } \\
\bullet \\
\bullet \text { New Brunswick } \\
\bullet \text { Onebec } \\
\bullet \text { Manitoba } \\
\bullet \text { Saskatchewan }\end{aligned}$ & $\begin{array}{c}2 \\
3 \\
43 \\
3 \\
3\end{array}$ \\
\hline Aboriginal Issues Workshop & 1 \\
\hline TOTAL & 117 \\
\hline
\end{tabular}

With the exception of the workshop on Aboriginal issues, each type of contact event took place at each of the five provinces in which the review was conducted, namely New Brunswick, Quebec, Ontario, Manitoba and Saskatchewan. Each type of contact event has been broken down by province.

During the Panel Review of the Nuclear Fuel Waste Management and Disposal Concept, there were 117 occasions in which the public had an opportunity to provide input. It is of importance to note that the greatest number of contact events took place in the province of 
Ontario, presumably because the proposed geological repository would most likely be situated in an area of the Canadian Shield in northern Ontario.

With respect to the number of events at which the proponent in each country made contact with the public regarding the nuclear waste issue, clearly there have been far more such events in Sweden than there were in Canada (approximately eight times more over roughly a similar given time period).

\subsubsection{Financial Resources Devoted to Public Engagement}

Figures regarding the amount of funding for public engagement activities in Canada and Sweden were obtained from the Report of the Nuclear Fuel Waste Management and Disposal Concept Environmental Assessment Panel and through personal correspondence with Sten Kjellman of SKB, respectively.

In Sweden, funding for nuclear waste management, including public engagement activities related to the siting work, is provided by the Nuclear Waste Fund (Lidskog and Andersson, 2002), as prescribed by the Financing Act, which states that "a reactor owner, in consultation with other reactor owners, shall calculate the costs for disposal of the spent fuel and radioactive waste" (SKB, 2003, pg. 13). The costs, which SKB has been commissioned to calculate and compile, are then factored into the costs of electricity production (SKB, 2003). The Nuclear Waste Fund provided an equivalent of $\$ 500,000$ CDN annually to local information organizations in the feasibility municipalities for such things as information dissemination and independent reviews of SKB's work. Thus, over the course of the eight years during which feasibility studies were conducted, a total of $\$ 4,000,000 \mathrm{CDN}$ was provided. 
In Canada, funding to assist the public in participating in the EA Panel Review was provided by AECL (CEAA, 1998). Initially, AECL had committed to providing $\$ 750,000$ for participant funding (CEAA, 1998). In the end, a total of $\$ 852,515$ was provided. These funds were disbursed on four occasions throughout the Panel Review, and required that a set of eligibility criteria be met (CEAA, 1998). A total of $\$ 152,500$ was distributed in September 1990 to assist members of the public in participating in the scoping meetings. A further $\$ 387,235$ was provided in October 1994 and $\$ 210,265$ in March 1995 to assist in reviewing the EIS and to participate in the public hearings. Lastly, $\$ 92,515$ was distributed in October 1996 to assist participants in reviewing supplementary information (CEAA, 1998).

A comparison of the total amount of funding that has been made available in Sweden and Canada for public engagement activities are presented in Table 9.

Table 9. Funding for public engagement activities in Sweden and the EA Panel Review in Canada.

\begin{tabular}{|c|c|}
\hline \multicolumn{1}{|c|}{ Proponent and Funding Type } & $\begin{array}{c}\text { Amount } \\
\text { (CDN \$) }\end{array}$ \\
\hline $\begin{array}{l}\text { Sweden - SKB } \\
\text { Local information organizations }\end{array}$ & $\mathbf{\$ 4 , 0 0 0 , 0 0 0}$ \\
\hline $\begin{array}{l}\text { Canada - AECL } \\
\text { Participant funding for Panel Review }\end{array}$ & $\mathbf{\$ 8 5 2 , 5 1 5}$ \\
\hline
\end{tabular}

Source: Personal correspondence with S. Kjellman, SKB and CEAA, 1998.

As is evident in the above table, there is a significant disparity in the amount of funding that has been provided for public engagement activities pertaining to nuclear waste management in Sweden and Canada. 


\subsection{Public Awareness of Nuclear Waste Issues and Support for NWM Programs}

Recent public opinion surveys regarding nuclear waste were examined to determine the level of the public's awareness of the nuclear waste issue in Sweden and Canada. In the Swedish case, the main survey consulted, entitled Europeans and Radioactive Wastes, was conducted by INRA (Europe) in 2001. The main survey used in the Canadian case was conducted by Navigator in 2003 for the Nuclear Waste Management Organization.

According to the EU survey, which asked, "How well informed do you think you are about radioactive waste?"29 the majority of Swedes (56.5\%) felt that they were "not very well informed" (Figure 8). On the other hand, 27.4\% of respondents replied that they were "fairly well informed". When combined with the $3.7 \%$ of respondents who felt they were "very well informed", roughly three out of ten Swedes can be said to be well informed abqut radioactive waste. Only $11.7 \%$ felt that they were "not at all well informed".

In Canada, the Navigator survey found that the public generally has low familiarity with nuclear waste (Figure 9). The exact question posed by the Navigator survey was "Using a scale between one and seven where one means you are not at all familiar and seven means you are very familiar, overall how familiar would you say you are with nuclear waste and how it is managed in Canada?" 30 The largest percentage of respondents (38\%) rated themselves a score of 1 ("not at all familiar"). A further $31 \%$ replied with a score of either 2

\footnotetext{
${ }^{29}$ Sample size was approximately 1000 interviews, with uncertainty levels between $1.9-3.1 \%$ (INRA, 2002).

${ }^{30}$ Sample size was 1901 interviews, with a margin of error of $+/-2.25 \%, 19$ times out of 20 .
} 
or 3 and a combined $21 \%$ gave a score of 4 or 5 . Only $5 \%$ of respondents felt that they were "very familiar", with a further $4 \%$ giving a score of 6 .

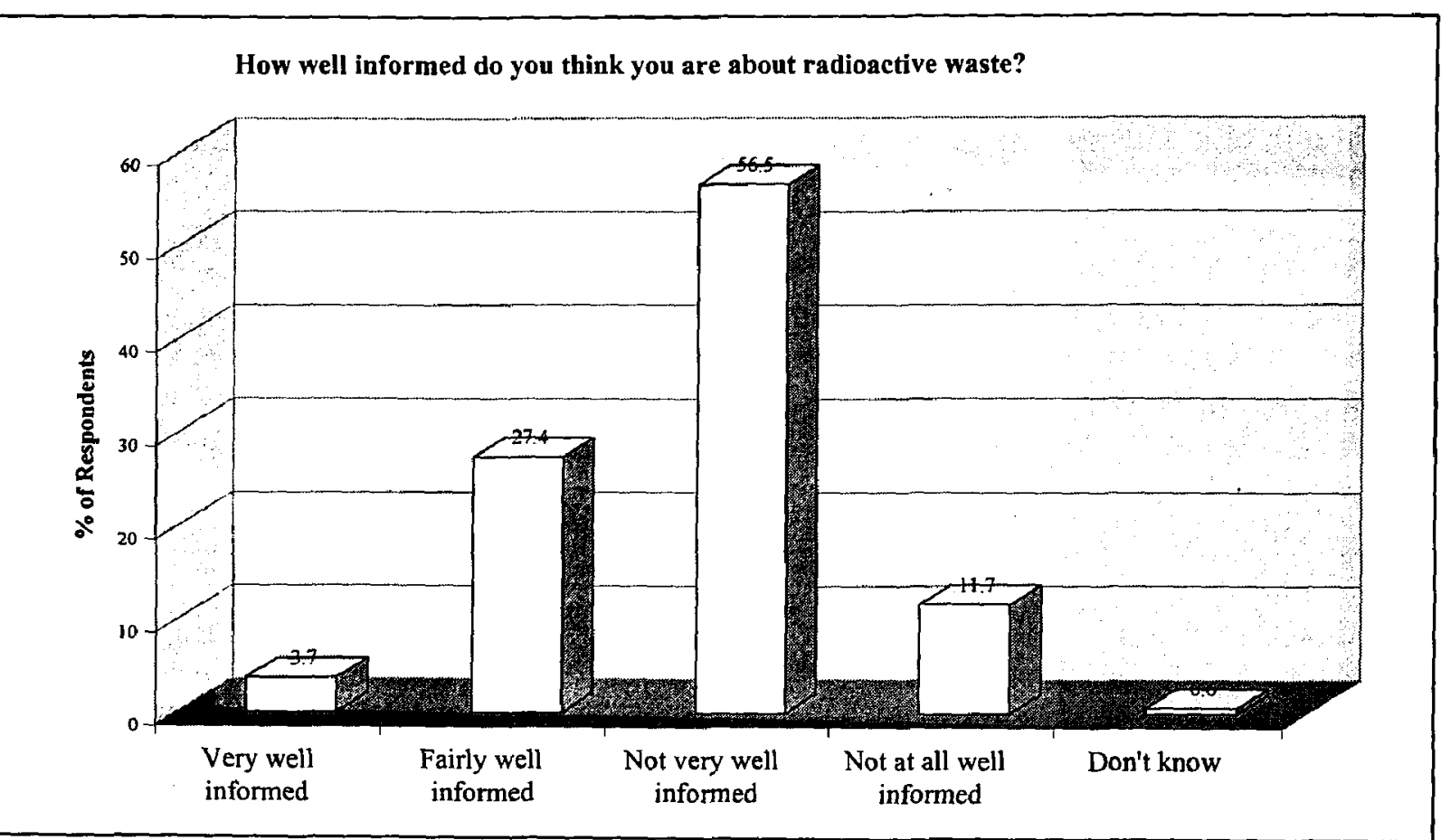

Figure 8. Swedish results of EU survey, Europeans and Radioactive Waste (INRA, 2002). 


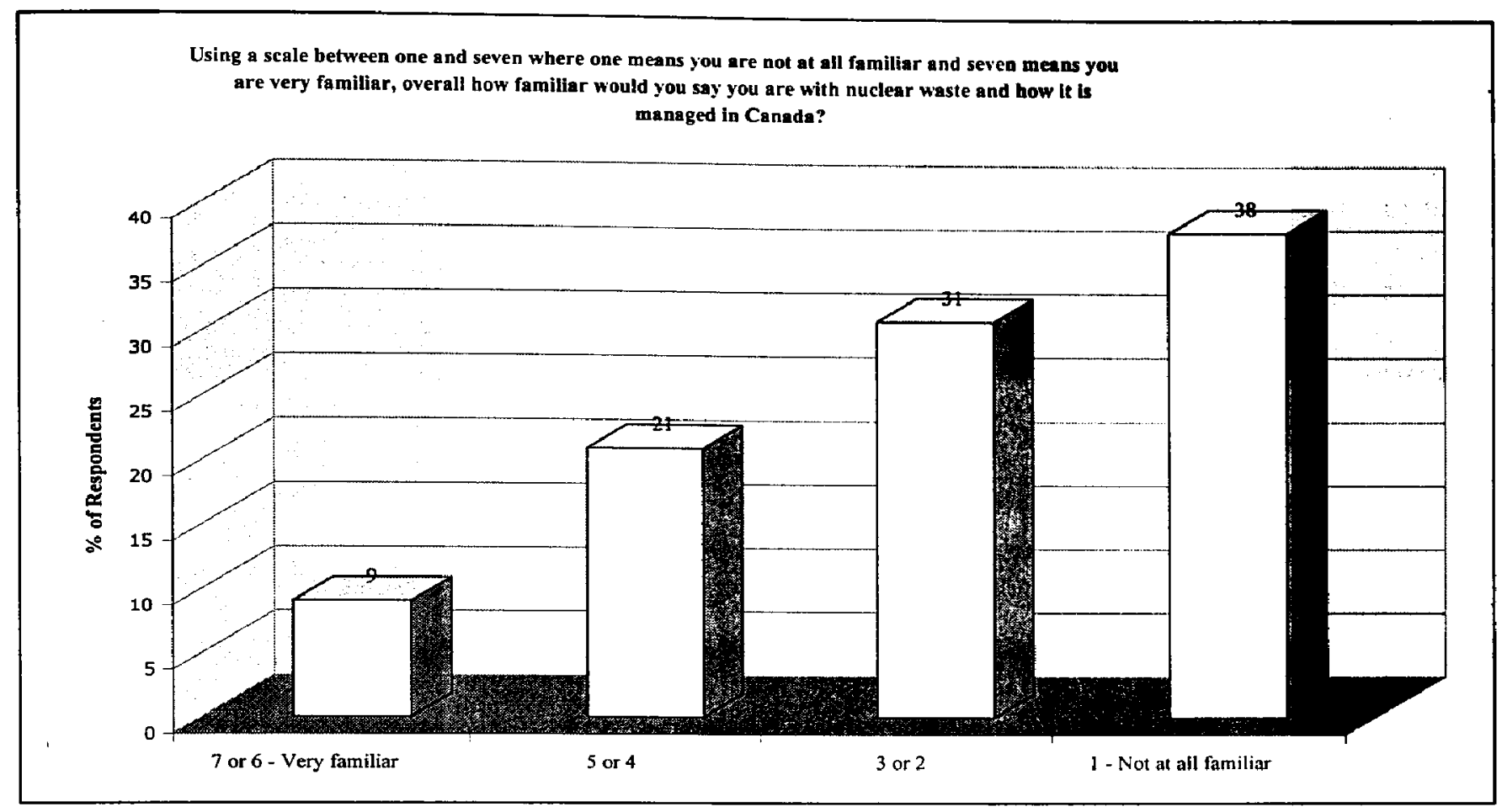

Figure 9. Results of survey, Public Attitudes to Nuclear Waste and the NWMO Project (Navigator, 2003).

The next survey question examined dealt with public support for the nuclear waste management programs in each country. The survey used in the Swedish case was conducted by the polling firm Temo for SKB regarding a deep repository (Temo, 2005). In the Canadian case, the survey used was conducted by Environics Research Group in 2003 for the Canadian Nuclear Association (Environics, 2003).

One of the questions posed in the Swedish survey was "If a suitable site for a deep repository can be found in your municipality, would you then be for or against an establishment?"31 (Figure 10). At the national level, $41 \%$ of respondents replied that they would be in favour of a deep repository. $51 \%$ responded that they were against a deep repository, with $8 \%$ being undecided. It should be noted that in the two municipalities currently undergoing detailed

\footnotetext{
${ }^{31}$ Sample size at the national level was 1000 interviews, and 800 interviews in each of Oskarshamn and Östhammar.
} 
site investigations, Oskarshamn and Östhammar, the percentage of respondents who were in favour of a deep repository were considerably higher at $76 \%$ and $71 \%$, respectively. This supports SKB's assertion that "the closer people live to a projected deep repository facility, the more they support it. This is probably due to the body of knowledge built up over a number of years" (Thegerström, 2004).

The question posed in the Canadian survey was "In general, would you say that you are very, somewhat, not very, or not at all confident that the authorities responsible for nuclear waste have a good system in place to deal with it?"32 Although this question is somewhat different from the question posed in the Swedish survey, it conveys a similar sentiment regarding support for the program or system in place for managing nuclear wastes. According to the

\footnotetext{
${ }^{32}$ Sample size was 2,018 interviews, with a margin of error of $+/-2.2 \%, 19$ times out of 20 .
} 


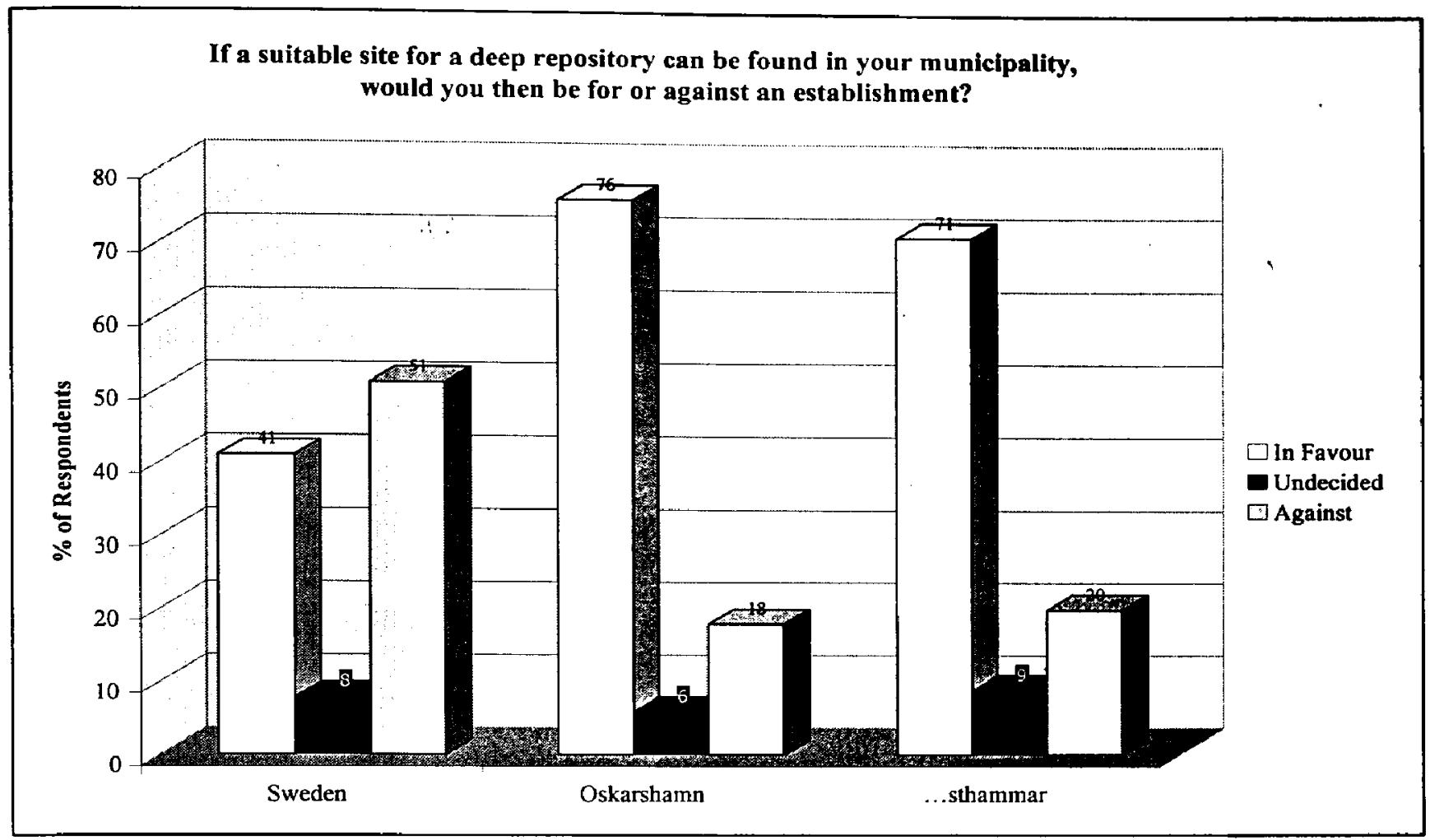

Figure 10. Results of SKB opinion survey regarding a deep repository (Temo, 2005)

In general, would you say that you are very, somewhat, not very, or not at all confident that the authorities responsible for nuclear waste have a good system in place to deal with it?

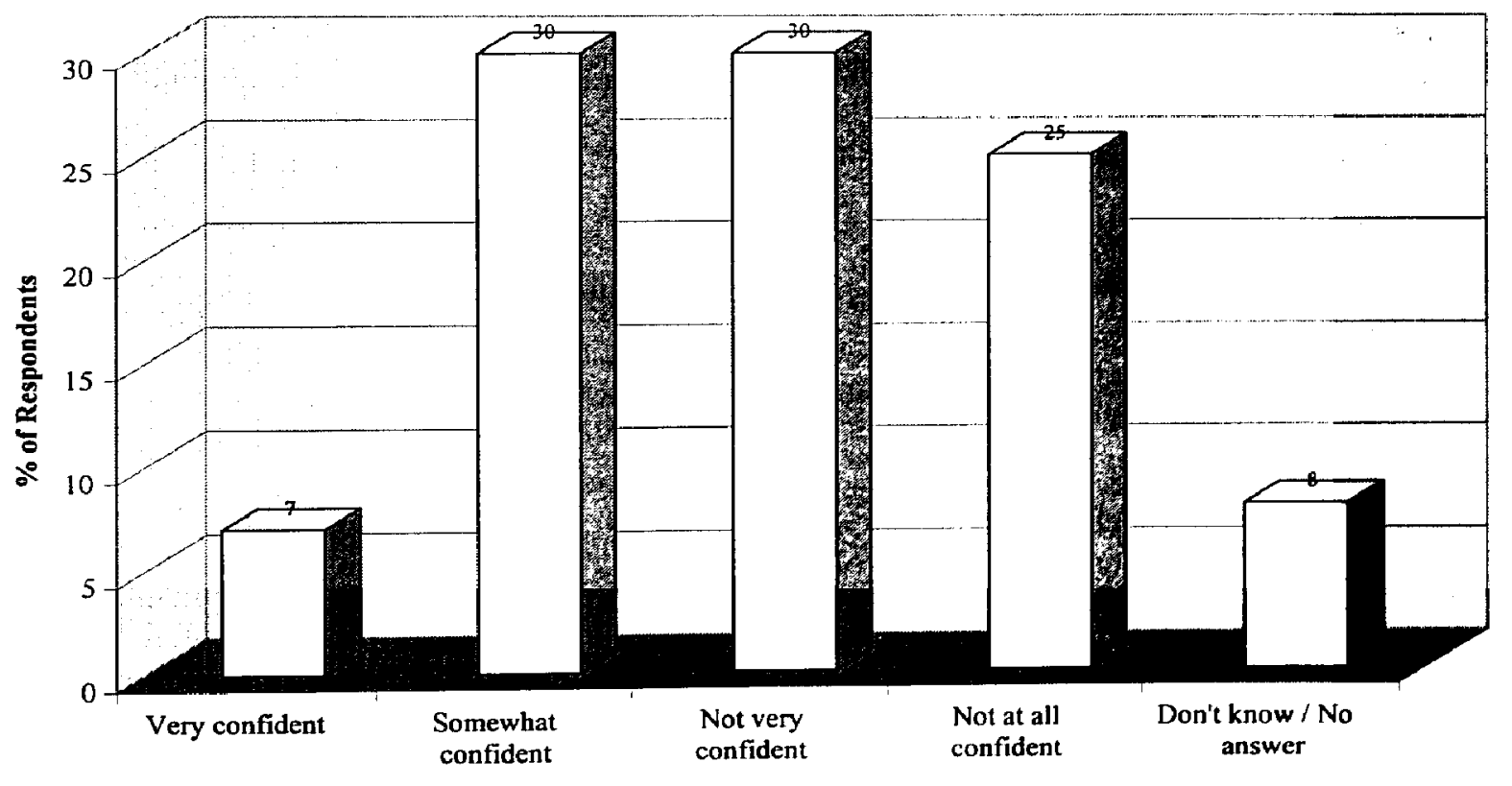

Figure 11. Survey results regarding the handling of nuclear waste in Canada (Environics, 2003). 
survey (Figure 11), only 7\% of Canadians are "very confident" in the system, with a further $30 \%$ being "somewhat confident". Thirty percent of respondents claimed they were "not very confident", while $25 \%$ were "not at all confident" that authorities had a good system for dealing with nuclear waste. 


\section{Discussion}

This thesis asks the question "How significant is effective public engagement in successfully implementing a nuclear waste management program?" It has discussed this question based on the understanding that the siting of a HLRW facility is both a public acceptance as well as a technical process. It has sought to answer this question through a comparative analysis of the public engagement programs of Sweden and Canada.

This three-part study utilized a review of primary and secondary sources to first compare the progress and current status of the nuclear waste management programs of Sweden and Canada. It also compared three specific measures of public engagement: access to information, level of contact and financial resources devoted to public engagement. Thirdly, a comparison was made between the effectiveness of each country's public engagement activities. This was done by comparing opinion surveys regarding public awareness of the nuclear waste issue and popular support for the nuclear waste management programs in each country.

Beyond the specific measures of public engagement examined in this study, there are other factors that have played a role in the progress of the Swedish nuclear waste management program, namely the strong role and close involvement of its nuclear regulatory authorities.

\subsection{Limitations}

Although every effort has been made to ensure thoroughness and accuracy in the analyses performed in this study, as has been previously mentioned, there were some limitations. 
With respect to the comparison of the levels of contact in each country, the most effective measure of the contact made between proponents and the public would have been a record of the actual number of individuals with whom contact was made. Unfortunately, the lack of attendance records during the open houses, scoping meetings and public hearings for the Canadian Panel Review did not make this possible. As a result, an analysis was instead performed on the number of events during which public contact was made.

With regard to the comparison of survey results to determine public support for each country's nuclear waste management program, the study was limited to the available surveys from each country. Unfortunately, the survey questions asked in each country did not explicitly ask the same question, thus cannot be fully regarded as yielding the same answers. However, the responses to both surveys, to a large degree, reflect the level of public support for their respective country's nuclear waste management programs.

\subsection{Conclusions}

The qualitative review of various primary and secondary source documents regarding the nuclear waste management programs of Sweden and Canada, which included reports from each country's nuclear authorities, government publications, journal articles, correspondence with various organizations, authorities and/or individuals, revealed that Sweden's nuclear waste management program has progressed much further than that of Canada. The timelines reveal that both countries began pursuing the idea of geological disposal at roughly the same time, but the Swedish KBS-3 method received government approval in 1983, while the Canadian concept has yet to be approved. Obtaining the government's approval for a disposal method can be seen as a significant milestone in the development of a nuclear waste 
management program. Thus, when considering the current status of each country's program, it can be said that the Swedish program is in fact more than twenty years ahead of the Canadian program in terms of obtaining approval for a disposal method and in the search for a disposal site. This finding is consistent with the literature, which acknowledges that Sweden, among all nuclear producing nations, is furthest along in the process of siting a HLRW facility.

The quantitative analyses performed on the three measures of public engagement revealed that the proponents of Sweden's nuclear waste management program have placed a much greater emphasis on public participation with respect to the nuclear waste management program than the proponents of the Nuclear Fuel Waste Management and Disposal Concept in Canada, as is evident in the Panel Review.

Sweden's nuclear authorities have made available to the public a far greater number of information materials than were made available during the Panel Review in Canada (127 in Sweden, compared to 57 in Canada). This demonstrates that Swedes have greater access to information regarding the nuclear waste management program than Canadians.

In addition to the sheer number of materials that have been published in Sweden, it is also of importance to note the type of materials that were made available. In Canada, the Federal Environmental Assessment and Review Office (FEARO) informed the public using two types of media: news releases and a periodical news bulletin entitled Dialogue. In Sweden, however, in addition to providing the public information through news releases, SKB produced brochures, a quarterly magazine, known as Lagerbladet, as well as videos and other reports describing the nuclear waste issue and proposed management program (Kjellman, 
2004). Although the effects of having different types of information material on the public's access to that information is beyond the scope of this study, it is likely that the greater variety in the types of information materials made available in Sweden would result in a greater penetration of the information into the general public.

Furthermore, it is also interesting to note the difference in the nature of the information materials published by each proponent regarding the nature and management of nuclear waste in general (not dealing with the siting or decision-making process). Although this study did not include a formal content analysis of the information materials, the difference in the nature of some of the reports from each country is worth mentioning. For instance, in December, 1989, FEARO informed the public of the availability of several documents, which would assist them in preparing for the scoping meetings (CEAA, 1998). These documents were An Issue Paper on the Management of Nuclear Fuel Wastes (Lura Group, 1989), A Review of Various Approaches Being Undertaken by Industrialized Nations for the Management and Disposal of High-Level Nuclear Waste (Acres International, 1989), and Managing Canada's Nuclear Fuel Wastes (AECL, 1989). A brief overview of these documents would reveal that they are rather technical in nature and thus perhaps not easily comprehensible to the average person. In Sweden, although " $[t]$ he principal cornerstone in building confidence consists of ensuring that SKB makes all its scientific and technical reports available to the public" (Lidskog and Andersson, 2002, pg. 75), the information material SKB published specifically for the public, such as Deep Repository for Spent Nuclear Fuel and This Is How We Manage Sweden's Radioactive Waste, was written using fairly simple language that nearly any member of society would be able to understand, regardless of their education level. These documents also contained numerous pictures and 
diagrams to illustrate the messages and ideas being conveyed. This is further evidence that the information provided in Sweden regarding nuclear waste has a much wider reach among the general public.

The distribution of these information materials is also of importance when considering public access to information. Comparing for the moment only the Swedish magazine Lagerbladet and the Canadian news bulletin Dialogue, it is important to note that while in the Canadian case, one had to be on the nuclear fuel waste management concept mailing list in order to receive the bulletin, in Sweden, the magazine is automatically sent to every single household in the two municipalities where site investigations are taking place, in addition to any individual or organization in the rest of the country who requests a copy. SKB also made its information available by electronic access through Sweden's libraries. This again is indicative of the greater penetration of information material in Sweden's general public than in Canada's.

A comparison of the number of visits to each country's nuclear research facilities revealed that Sweden's nuclear research facilities have hosted a far greater number of visitors than their Canadian counterpart. As nuclear research facilities may be considered direct sources of information about nuclear waste and nuclear waste management, the greater number of visitors to Sweden's Äspo HRL $(89,468$, compared to 9,648 to AECL's URL) is further evidence that, with regard to nuclear waste and nuclear waste management, the Swedish public has been given greater access to information. Although it may be argued that perhaps there have been a greater number of visitors to Sweden's Äspo HRL than AECL's URL simply because the Äspo HRL is more conveniently located than AECL's URL, the fact that there was a sharp increase in the number of visitors to the Äspo HRL during the peak of the 
feasibility study activities suggests that it is not just a matter of convenience, but rather a reflection of the proponent (SKB's) level of outreach.

The next public engagement measure that was analyzed was the level of contact that the proponents in each country engaged in with the public regarding the nuclear waste issue. The results of the analysis revealed that the Swedish Nuclear Fuel and Waste Management Company (SKB) made contact with the public 807 times between 1992-2004, as compared to the 117 contact events hosted by the Canadian EA Panel. The amount of contact that SKB has made with the public can be seen as the foundation of the Swedish voluntary process for siting its deep geological repository for spent nuclear fuel. In a lecture presented by SKB at the Sixth European Commission (EC) and international conference on the management and disposal of radioactive waste (Euradwaste '04) "the importance of the involvement of stakeholders in the process of decision-making and implementation was stressed" (Thegerström et al., 2004). The presenters further noted that "[d]ialogue and transparency is (sic) necessary to build the broad social trust needed for a fair and successful decision process" (Thegerström et al., 2004). Although there are certainly numerous other factors that, together, have accounted for the opposition to the Canadian disposal concept, it is clear from the research literature and the empirical evidence that, in itself, insufficient contact with and involvement by the public in the nuclear waste issue has been the main downfall of the Canadian nuclear waste management program, and may in large measure explain the failure of its voluntary siting initiative.

The third public engagement measure that was analyzed in this study was the amount of funding that was allocated by the proponents in each country for public participation activities. It is clear from the comparison that there is a huge disparity between the amount 
of public participation funding made available in Sweden and Canada. The amount provided by AECL to assist the public in participating in the EA Panel Review $(\$ 852,515)$ is merely a fraction of the total amount allocated by the Nuclear Waste Fund to the local information organizations in each of the feasibility study municipalities (the equivalent of $\$ 4,000,000$ $\mathrm{CDN}$ ). As has been reported in the research literature, the lack of effort and funding in enlisting the public to help find a solution to the nuclear waste dilemma can only lead to continued opposition (Flynn et al., 1992). SKB's funding has provided the public and municipalities with the tools and means to objectively review their work, extend their knowledge of the nuclear waste issue and have a meaningful role in the decision-making process. This is clearly a significant factor in the support for and acceptance of Sweden's plans for a deep geological repository.

The final analysis conducted in this study was a comparison of the levels of public awareness of the nuclear waste issue and public support for the respective nuclear waste management programs of each country. This was done to verify the effectiveness of each country's public engagement activities. With respect to the public awareness of nuclear waste issues, the analysis revealed that in both Sweden and Canada, the percentage of each population that claimed to have a high level of awareness was quite low (3.7\% in Sweden reported they were very well informed, while a combined $9 \%$ in Canada reported high familiarity). At the other end of the spectrum, the surveys revealed that in Sweden, only $11.7 \%$ of the population reported that they were "not at all well informed" about radioactive waste. This is considerably less than the percentage Canadians who reported that they were "not at all familiar" $(38 \%)$. Alternatively, roughly $88 \%$ of Sweden's population has at least some limited knowledge of nuclear waste, while in Canada the comparable figure is only $61 \%$. 
This suggests that the public engagement activities conducted by Sweden's nuclear authorities have been considerably more effective at penetrating the awareness of the general population than those of their Canadian counterparts.

$(3$

With regards to public support for nuclear waste management programs, it would appear from the comparison of the survey results that support for the nuclear waste management system in Sweden is significantly greater than in Canada. At the national level, $41 \%$ of Swedes would accept a deep repository if it were to be found in their municipality (Temo, 2005). Although in Canada, the siting process has not been reached, it may be presumed that acceptance of a deep repository must be preceded by a high level of confidence in the nuclear authorities and the nuclear waste management system in place. According to an Environics survey, only $7 \%$ of Canadians reported having this high level of confidence (Environics, 2003). Thus it may be concluded that the public engagement efforts of Sweden's nuclear authorities have been successful at not only increasing public awareness of the nuclear waste issue, but also increasing public support for its nuclear waste management program. This conclusion is supported by the fact that support for a deep repository is even greater in the two municipalities undergoing detailed site investigations (76\% in Oskarshamn and $71 \%$ in Östhammar), where public engagement activities are high and the public has greater awareness.

While it is true that the Canadian process has not progressed to the point where specific potential sites have been identified, clearly the inadequacy of the EA Panel to effectively engage the public in the nuclear waste issue and its failure to provide the public with a meaningful role in the decision making process has resulted in low public awareness of the 
issue, and as naturally follows, low confidence (support) for the nuclear waste management program.

Through the analyses performed in this study, it is clearly evident that Sweden has taken great strides in its voluntary process to site a deep repository for its spent nuclear fuel. SKB has produced and made available to the public a large amount of information through several means to increase the public's knowledge of nuclear waste, the nuclear waste issue, and its proposed method for disposing of nuclear waste. It has actively engaged the public and maintained a strong presence in the public eye, as is evidenced by the large number of contact events it has hosted or participated in. Its commitment to involving the public has also been proven through the amount of financial resources they allocate to public information activities. This study has shown that these efforts have paid off. The nuclear waste issue is something that the majority of Swedes is at least somewhat aware of, with 4 out of 10 Swedes willing to accept a repository in their municipality. This study has provided empirical evidence that the progress of the Swedish nuclear waste management strategy is directly attributable to the efforts of SKB to involve the public in the decision making process.

This study has also shown the inadequacy of the avenues for public participation during the Canadian Panel Review of the Nuclear Fuel Waste Management and Disposal Concept. The analyses of public engagement measures found the Canadian case to be substandard compared to the Swedish case in all three measures (number of information materials published, level of contact and financial resources devoted to public engagement). This may be attributed to the fact that public participation during the Panel Review was limited to the requirements of the Environmental Assessment and Review Process Guidelines Order, 
namely scoping meetings and public hearings. The Panel Review's finding that AECL's concept did not have broad social acceptability and thus, could not likely be stied is clear evidence of the inadequacies of the public participation process.

In November of this year, the Nuclear Waste Management Organization will be releasing its $\therefore$ final recommendations with respect to the long-term management of Canada's nuclear fuel Wastes. Since 2002, the NWMO has sought to get Canadians involved in identifying important issues, developing a framework with which to analyze nuclear waste management .approaches and providing recommendations with respect to the preferred management approach (NWMO, 2003). Although a formal analysis of the public engagement measures that have been undertaken by the NWMO is not included in this study, it seems apparent that their efforts to collaboratively develop a management approach have been a significant improvement over the status quo that was evident during Panel Review. It reflects the NWMO's recognition of the shortcomings of the previous process and of the level of effort that is required in order to have a successful nuclear waste management program in Canada.

It is pertinent at this point to discuss another factor, which, in the author's opinion, has also played a significant role in the success of the Swedish process. Although this thesis has focused on public participation in the nuclear waste siting process, throughout the course of this research, the importance of a strong presence of nuclear regulatory authorities became quite evident. In Sweden, for instance, the two regulatory authorities, namely the Swedish Nuclear Power Inspectorate (SKI)) and the Swedish Radiation Protection Authority (SSI) have maintained an active role throughout the siting process. With SKB being responsible for the handling and disposal of nuclear wastes, one of the roles of SKI and SSI is to ensure that SKB lives up to this responsibility (Westerlind and Hedberg, 2000). For example, all of 
SKB's research regarding final disposal of spent nuclear fuel is subject to review by both SKI and SSI (SKI, 2005; SSI, 2004). The regulatory authorities, particularly SSI, are also responsible for ensuring compliance with radiation protection regulations.

In addition to the above duties that have been set out by Swedish legislation ${ }^{33}$, SKI and SSI have taken their responsibilities one step further by becoming more active in the siting process. One of the reasons for this was an increased demand from municipalities for greater presence from the regulatory authorities, having been viewed as independent and credible government bodies (Westerlind and Hedberg, 2000). Since about 1995, SKI and SSI have played an active role in the consultations, investigations and decision-making process.

Furthermore, SKI and SSI have undertaken joint projects, such as the joint information project, which began in 1997 (SSI, 2004). The aim of the information project is "to clarify [the regulatory authorities'] roles and responsibilities, and increase knowledge about radiation, radiation protection and nuclear waste safety issues" (Pensjö, 2004, pg. 1). The activities that have been conducted under this joing information project include study trips, seminars, education programs for teachers, exhibitions, surveys, as well as the publication of various types of information materials (SSI, 2004). SKI and SSI have also conducted research relating to risk communication and transparency in decision making processes. The joint research project, dubbed RISCOM, began as a pilot project 1998 and sought to "understand how facts, expert judgment and value judgment interact to form the basis of a decision" (Westerlind and Hedberg, 2000, pg. 113). Its overall objective is to aid in the development of transparency in nuclear waste management programs (Andersson et al., 2003). The research led to, among other things, the design of public hearings, which

${ }^{33}$ Act on Nuclear Activity (Kärntekniklagen 1984:3), Radiation Protection Act (Strålskyddslagen 1988:220). 
previously had not been used in Swedish decision-making processes, as part of the review of SKB's proposal of candidate sites for a deep repository (Andersson et al., 2003).

The high degree of involvement of the regulatory authorities in Sweden has further increased the public's trust, which makes the acceptance of a disposal method and eventual site all the more likely. This involvement was not evident during the Canadian Panel Review. Canada's nuclear regulatory body, the Atomic Energy Control Board (AECB) was conspicuously absent throughout most of the public hearings, leaving the proponent (AECL) to field most of the questions. Although it is beyond the scope of this thesis, the experience of the Swedish regulatory authorities would seem to indicate that greater involvement and a stronger presence on the part of AECB in the future could also facilitate greater social acceptance of a nuclear waste strategy.

This study has shown that in order to achieve a successful nuclear waste management program and siting process, the public must be adequately informed and meaningfully involved. The work of the NWMO, although far from being completed, has indicated that the Canadian process is slowly moving in this right direction. Although the siting of nuclear and other hazardous waste facilities using the classic Decide-Announce-Defend approach is now widely recognized as unwise and futile, most nuclear producing nations have yet to adopt an open voluntary process in their nuclear decision making. It is the author's hope that this research has shed some light on the virtues of meaningful public participation, and helps to unravel the nuclear waste siting dilemma. 


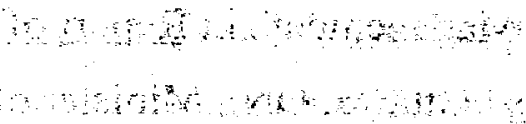

\section{REFERENCES}

Acres International. 1989. A Review of Various Approaches Being Undertaken by

Industrialized Nations for the Management and Disposal of High-level Nuclear Waste.

Niagara Falls, ON: Acres International.

Ahearne, J. 1987. "Nuclear Power After Chernobyl”, Science 236:4082, pp. 673-679.

Ahlström, P. 1997. "Towards a Swedish repository for spent fuel." Nuclear Engineering and Design 176, 67-74.

Aikin, A.M., J.M. Harrison and F.K. Hare (Chairman). 1977. The Management of Canada's Nuclear Wastes. Report of a study prepared under contract for the Minister of Energy Mines and Resources Canada, Report EP 77-6.

Aikin, A.M., J.M. Harrison and F.K. Hare (Chairman). 1977. The Management of Canada's Nuclear Wastes. Ottawa, ON: Minister of Supply and Services Canada.

Andersson, K. et al. 2003. Design and Evaluation of Public Hearings for Swedish Site Selection: A report from the RISCOM II Project. Stockholm, Sweden: SKI.

Andersson, K. et al. 2003. Transparency and Public Participation in Radioactive Waste Management: RISCOM II Final Report. Stockholm, Sweden: SKI.

Andersson, K., R. Espejo and C.O. Wene. 1998. Building Channels for Transparent Risk Assessment: Final Report RISCOM Pilot Project. Stockholm, Sweden: SKI and SSI.

Atomic Energy of Canada Limited. 1989. Managing Canada's Nuclear Fuel Wastes. Pinawa, MB: AECL.

Atomic Energy of Canada Limited. 1994. Environmental Impact Statement on the Concept for Disposal of Canada's Nuclear Fuel Waste. Pinawa, MB: AECL.

Atomic Energy of Canada Ltd. 1994. Environmental Impact Statement on the Concept for Disposal of Canada's Nuclear Fuel Waste. Pinawa, MB: AECL. 
Auditor General of Canada. 1997. "Federal Radioactive Waste Management" in Report of the Auditor General of Canada to the House of Commons. Ottawa, ON: Minister of Supply and Services Canada.

Bingham, G. and D.S. Miller. 1984. "Prospects for Resolving Hazardous Waste Siting Disputes Through Negotiation", Natural Resources Lawyer 17:3, pp. 473-490.

Bjarnadóttir, H. and T. Hilding-Rydevik. 2001. Final disposal of spent nuclear fuel in Sweden: some unresolved issues and challenges in the design and implementation of the forthcoming planning and EIA processes. Stockholm, Sweden: Nordregio Nordic Centre for Spatial Development. [http://www.nordregio.se/Files/ep0103.pdf]

Bjurstrom, S. 1989. "Storage of Nuclear Waste in Sweden." Tunneling and Underground Space Technology 4:2, pp. 139-142.

Boulton, J, ed. 1978. Management of Radioactive Fuel Wastes: The Canadian Disposal Program. Pinawa, MB: Atomic Energy of Canada Limited.

Brotzen, O. 1995. "Public Acceptance and Real Testing of a Nuclear Repository" in Waste Management 15:8, pp. 559-566.

Brown, P.A. 2003. “Canada's New Nuclear Fuel Waste Act" in 2003 Proceedings $9^{\text {th }}$ International Conference on Environmental Remediation and Radioactive Waste Management, 21-25 September, 2003, Oxford, England. Oxford, England: American Society of Mechanical Engineers.

Canadian Environmental Assessment Agency - Nuclear Fuel Waste Management and Disposal Concept Environmental Assessment Panel. 1998. Nuclear fuel waste management and disposal concept: report of the Nuclear Fuel Waste Management and Disposal Concept Environmental Assessment Panel. Hull, PQ: Minister of Public Works and Government Services Canada.

Canadian Environmental Assessment Agency. 1995. An Evaluation of the Environmental Impact Statement on Atomic Energy of Canada Limited's Concept for the Disposal of 
Canada's Nuclear Fuel Waste: Report of the Scientific Review Group. Ottawa, ON: Minister of Supply and Services Canada.

Canadian Environmental Assessment Agency. 1996. An Evaluation of the Environmental Impact Statement on Atomic Energy of Canada Limited's Concept for the Disposal of Canada's Nuclear Fuel Waste: An Addendum to the Report of the Scientific Review Group. Ottawa, ON: Minister of Supply and Services Canada.

Canadian Environmental Assessment Agency. 2003. Basics of Environmental Assessment. [http://www.ceaa-acee.gc.ca/010/basics_e.htm\#5].

Canadian Nuclear Association. 2004. Number of Operating Reactors in Canada (2004). Ottawa, ON: CAN. [http://www.cna.ca/english/Nuclear_Facts/operatingreactorscanada_April_04.pdf].

Canadian Nuclear Safety Commission. 2003. Canadian National Report for the Joint Convention on the Safety of Spent Fuel Management and on the Safety of Radioactive Waste Management. Ottawa, ON: Canadian Nuclear Safety Commission.

Carter, L. 1987. "Siting the Nuclear Waste Repository: Last Stand at Yucca Mountain" in Environment 29:8, pp. 8-31.

Carter, L.J. 1987. Nuclear Imperatives and Public Trust: Dealing with radioactive waste. Washington, DC: Resources for the Future.

Carter, L.J. 1997. "It's time to lay this waste to rest" in Bulletin of the Atomic Scientists 53:1, pp.13-15.

Castle, G. and D. Munton. 1996. "Voluntary Siting of Hazardous Waste Facilities in Western Canada" in Munton, D., ed. 1996. Hazardous Waste Siting and Democratic Choice. Washington, DC: Georgetown University Press.

Central Intelligence Agency. 2005. The World Factbook. Washington, DC: Central Intelligence Agency. 
Covello, V. et al., eds. 1987. Uncertainty in Risk Assessment, Risk Management, and Decision-Making. New York, NY: Plenum Press.

Davison, C.C., A. Brown, R.E. Everitt, M. Gascoyne, E.T. Kozak, G.S. Lodha, C.D. Martin, N.M. Soonawala, D.R. Stevenson, G.A. Thorne and S.H. Whitaker. 1994. The Disposal of Canada's Nuclear Fuel Waste: Site Screening and Site Evaluation Technology. Pinawa, MB: AECL.

Decamps, F. and L. Dujacquier. 1997. "Overview of European practices and facilities for waste management and disposal." Nuclear Engineering and Design 176, 1-7.

Department of Justice Canada. 2002. Nuclear Fuel Waste Act. Ottawa, ON: Department of Justice Canada. [http://laws.justice.gc.ca/en/N-27.7/86844.html]

Duncan, I.J. 2002. "Disposal of radioactive waste: a puzzle in four dimensions", Nuclear Energy $41: 1$, pp. $75-80$.

Dunlap, R., M. Kraft and E. Rosa. 1993. Public Reactions to Nuclear Waste: Citizens' views of repository siting. Durham, NC: Duke University Press.

Easterling, D. 1992. "Fair rules for siting a high-level nuclear waste repository", Journal of Policy Analysis and Management 11, pp. 442-475.

Easterling, D. and H. Kunreuther. 1995. The Dilemma of Siting a High-Level Nuclear Waste Repository. Norwell, MA.: Kluwer Academic Publishers

Flynn, J., J. Chalmers, D. Easterling, R. Kasperson, H. Kunreuther, C.K. Mertz, A. Mushktel, K.D. Pijawka, P. Slovic and L. Dotto. 1995. One Hundred Centuries of Solitude: Redirecting America's High-Level Nuclear Waste Policy. Boulder, CO: Westview Press.

Flynn, J., R. Kasperson, H. Kunreuther and P. Slovic. 1992. "Time to rethink nuclear waste storage", Issues in Science and Technology 8:4, pp. 42-48. 
Freundenburg, W.R. 2004. "Can we learn from Failure? Examining US experiences with nuclear repository siting", Journal of Risk Research 7:2, pp. 153-169.

Gerrard, M.B. 1994. Whose Backyard, Whose Risk: Fear and fairness in toxic and nuclear waste. Cambridge, MA: MIT Press.

Haussman, F.C. and P.G. Mueller. 2003. Long-Term Management of Nuclear Fuel WasteIssues and concerns raised at nuclear facility sites 1996-2003. Toronto, ON: Nuclear. Waste Management Organization.

Hesketh, K.W. 1996. Power Reactors, in Wilson, P.D., ed.

Hine, D.W., C. Summers, M. Prystulpa and A. McKenzie-Richer. 1997. "Public opposition to a proposed nuclear waste repository in Canada: an investigation of cultural and economic effects", Risk Analysis 7, pp. 293-302.

Högberg, L., S. Norrby and B. Dverstorp. Undated. How can we dispose of nuclear waste for hundreds of thousands of years? Stockholm, Sweden: The Swedish Nuclear Power Inspectorate (SKI). [http://www.ski.se/dynamaster/file_archive/010822/64669826924/howdispose.pdf]

Hore-Lacy, I. 2003. Nuclear Electricity. Melbourne, AU: Uranium Information Centre Ltd.

Inhaber, H. 1998. Slaying the NIMBY Dragon. New Jersey: Transaction Publications.

Inhaber, H. 1991. "A market-based solution to the problem of nuclear and toxic waste disposal", Journal of the Air and Waste Management Association 41, pp. 808-816.

International Atomic Energy Agency. 2003. Country Nuclear Profiles: Sweden. Vienna, Austria: IAEA. [http://wwwpub.iaea.org/MTCD/publications/PDF/cnpp2003/CNPP_Webpage/countryprofiles/S weden/Sweden2003.htm]

International Atomic Energy Agency. 1993. Report on Radioactive Waste Disposal. IAEA TR no. 34. 
Jacob, G. 1990. Site Unseen: The Politics of Siting a Nuclear Waste Repository. Pittsburgh, PA: University of Pittsburgh Press.

Johansson, C. 2003. Radioactive Waste Management in Sweden - Experiences and Plans. Stockholm, Sweden: SKB.

Kasperson, R.E., O. Renn, P. Slovic, H.S. Brown, J. Emel, R. Goble, J.X. Kasperson and S. Ratick. 1988. "The Social Amplification of Risk: A Conceptual Framework", Risk Analysis 9:4, pp. 543-550.

Kemp, R. 1992. The Politics of Radioactive Waste Disposal. Manchester: Manchester University Press.

Kjellman, S. 2004. Personal correspondence via electronic mail.

Kjellman, S. No Date. Deep Repository and Encapsulation Plant for Spent Nuclear Fuel Consultations and Communications. Stockholm, Sweden: SKB.

Kraft, M.E. and B.B. Clary. 1993. "Public Testimony in Nuclear Waste Repository Hearings: A Content Analysis" in Dunlap, R., M. Kraft and E. Rosa. 1993. Public Reactions to Nuclear Waste: Citizens' views of repository siting. Durham, NC: Duke University Press.

Kraft, Michael E. 2000. "Policy Design and the Acceptability of Environmental Risks: Nuclear waste disposal in Canada and the United States" in Policy Studies Journal 28:1, pp. 206-218.

Krauskopf, K. 1990. "Disposal of High-Level Nuclear Waste: Is it possible?" in Science 249, pp. 1231-1232.

Kuhn, R.G. 1998. "Social and political issues in siting a nuclear-fuel waste disposal facility in Ontario, Canada" in Canadian Geographer 42:1, pp. 14-28. 
Kuhn, R.G. \& B.L. Murphy. 2001. "Setting the terms of reference in environmental assessments: Canadian nuclear fuel waste management" in Canadian Public Policy $27: 3,249-266$.

Kunreuther, H. 1996. "Voluntary Procedures for Siting Noxious Facilities: Lotteries, Auctions, and Benefit Sharing" in Munton, D., ed. 1996. Hazardous Waste Siting and Democratic Choice. Washington, DC: Georgetown University Press.

Kunreuther, H., P. Slovic, \& D.G. MacGregor. 1996. "Risk perception and trust: Challenges for facility siting" in Risk: Health, Safety \& Environment 7, pp. 109-118

Kunreuther, H., W. Desvouges and P. Slovic. 1988. "Nevada's Predicament: Public perceptions of risk from the proposed nuclear waste repository" in Environment 30:8, pp. 16-.

Lake, R. 1993. "Rethinking NIMBY" in American Planning Association Journal 59:1, pp. $87-93$.

Lidskog, R. and A.C. Andersson. 2002. The Management of Radioactive Waste: A description of ten countries. Stockholm, Sweden: SKB.

Lidskog, R. and G. Sundqvist. 2004. "On the right track? Technology, geology and society in Swedish nuclear waste management" in Journal of Risk Research 7:2, pp. 251-268.

Lura Group. 1989. An Issue Paper on the Management of Nuclear Fuel Wastes. Toronto, ON: Lura Group.

Lyon, R. and M. Tutiah. 1984. Nuclear Fuel Waste Management: Protecting the Future. Ottawa, ON: Atomic Energy of Canada Limited.

Ministry of the Environment. 2003. Sweden's first national report under the Joint Convention on the safety of spent fuel management and on the safety of radioactive waste management. Stockholm, Sweden: Ministry of the Environment. [http://www.ski.se/dynamaster/file_archive/030423/3ac68b07a100a3ab0d4c74e968a0 2cba/SKI\%5fK\%e4mavfallskonventionsrapport.pdf] 
Mohanty, S. and B. Sagar. 2002. "Importance of Transparency and Traceability in Building a Safety Case for High-Level Nuclear Waste Repositories" in Risk Analysis 22:1, pp. 7-15.

Munton, D., ed. 1996. Hazardous Waste Siting and Democratic Choice. Washington, DC: Georgetown University Press.

Murdock, S.H., F.L. Leistritz, and R.R. Hamm. 1983. Nuclear Waste: Socioeconomic Dimensions of Long-Term Storage. Boulder, CO: Westview Press.

Natural Resources Canada. 2002. Backgrounder: The Nuclear Fuel Waste Act. Ottawa, ON: Natural Resources Canada.

[http://www.nrcan.gc.ca/media/newsreleases/2002/2002127a_e.htm]

Nuclear Energy Agency. 2000. Stakeholder Confidence and Radioactive Waste Disposal. Workshop Proceedings, Paris, France, 28-31 August 2000. Paris, France: OECD NEA.

Nuclear Waste Management Organization. 2003. About NWMO. Toronto, ON: NWMO. [http://www.nwmo.ca/Default.aspx?DN=37,18,1,Documents]

Nuclear Waste Management Organization. 2003. Asking The Right Questions: The Future Management of Canada's Used Nuclear Fuel. Toronto, ON: NWMO.

Nuclear Waste Management Organization. 2003. NWMO Approach to Development of Analytical Framework. Toronto, ON: NWMO

Ontario Legislative Assembly - Select Committee on Ontario Hydro Affairs. 1977. Management of Nuclear Fuel Waste - Final Report. Toronto, ON: The Legislative Assembly of Ontario.

Pensjö, A. 2004. SSI/SKI's Information Project. Stockholm, Sweden: Swedish Radiation Protection Authority. 
Rabe, B.G. 2000. "Beyond Siting: Implementing voluntary hazardous waste siting agreements in Canada" in American Review of Canadian Studies 30:4, pp. 479-.

Rabe, B.G. 1994. Beyond NIMBY: Hazardous Waste Siting in Canada and the United States. Washington, DC: The Brookings Institution.

Rabe, B.G. 1996. Presentation by Dr. Barry Rabe, University of Michigan (Invited Speaker). Pickering, ON: CEAA. [http://www.ceaa.gc.ca/010/0001/0001/0012/0002/0007/s8_e.htm]

Ritcey, G.M. 1996. Mining and milling uranium ore, in Wilson, P.D., ed. 1996. The Nuclear Fuel Cycle: from ore to wastes. Oxford: Oxford University Press.

Rosa, E. A. and W.R. Freudenburg. 1993. "The Historical Development of Public Reactions to Nuclear Power: Implications for Nuclear Waste Policy" in Dunlap et al. 1993. Public Reactions to Nuclear Waste.

Rouben, 1998. The Nuclear Fuel Cycle. Chalk River, ON: Atomic Energy of Canada Limited.

Rummery, T.E., and E.L.J. Rosinger. 1981. Nuclear Fuel Waste Management: The Canadian Approach. Pinawa, MB: AECL.

Short, J.F., Rosa, E.A. 2004. "Some principles for siting controversy decisions: lessons from the US experience with high level nuclear waste" in Journal of Risk Research 7:2, pp. 135-152.

Shrader-Frechette, K.S. 1993. Burying Uncertainty: Risk and the case against geological disposal of nuclear waste. Berkeley, CA: University of California Press.

Sjöberg, L. 2004. "Local Acceptance of a High-Level Nuclear Waste Repository" in $\underline{\text { Risk }}$ Analysis 24:3, pp. 737-749. 
Sjöberg, L. 2002. Risk communication between experts and the public: perceptions and intentions. SSE/EFI Working Paper Series in Business Administration No 2003:13. Stockholm, Sweden: Center for Risk Research - Stockholm School of Economics.

Sjöberg, L. 2003. "Attitudes and Risk Perceptions of Stakeholders in a Nuclear Waste Siting Issue." Risk Analysis 23:4, 739-749.

Sjöberg, L. and B. Drottz-Sjöberg. 1997. "Physical and Managed Risk of Nuclear Waste." Risk: Health, Safety and Environment 8:1, pp. 115-122.

Sjöberg, L. and B. Drottz-Sjöberg. 2001. "Fairness, risk and risk tolerance in the siting of a nuclear waste repository." Journal of Risk Research 4:1, 75-101.

Slovic, P. 1987. "Perception of Risk" in Science 236, pp. 280-285.

Slovic, P., J. Flynn and M. Layman. 1991. "Perceived risk, trust and the politics of nuclear waste" in Science 254, pp. 1603-1607.

Smith, K.R. 1988. "Perception of Risks Associated with Nuclear Power" in Energy Environment Monitor 4:1, pp. 61-70.

Soloway, S.M. 2003. "International progress on geological disposal" in Nuclear Engineering International November 2003, pp. 20-22.

Stone, R. 2004. “Deep Repositories: Out of sight, out of terrorists' reach" in Science 303, pp. 161-164.

Summers, C. and D.W. Hine. 1997. "Nuclear waste goes on the road: risk perception and compensatory tradeoffs in single-industry communities" in Canadian Journal of Behavioral Science 29, pp.11-13.

Swedish Nuclear Fuel and Waste Management Co. 2000. Integrated account of method, site selection and programme prior to the site investigation phase. Stockholm, Sweden: SKB. 
Swedish Nuclear Fuel and Waste Management Co. 2003. Plan 2003: Costs for management of the radioactive waste products from nuclear power production. Stockholm, Sweden: SKB.

Swedish Nuclear Fuel and Waste Management Co. 2004 ${ }^{\mathrm{a}}$. RD\&D - Programme 2004:

Programme for research, development and demonstration of methods for the management and disposal of nuclear waste, including social science research. Stockholm, Sweden: SKB.

Swedish Nuclear Fuel and Waste Management Co. 2004 . Extended Consultations According to the Environmental Code. Stockholm, Sweden: SKB.

Swedish Nuclear Fuel and Waste Management Co. $2004^{\mathrm{c}}$. Press Release - Swedish nuclear waste programme: Research well advanced as decision phase approaches. Stockholm, Sweden: SKB.

Swedish Nuclear Fuel and Waste Management Co. 2004 ${ }^{\mathrm{d}}$. Activities 2003. Stockholm, Sweden: SKB.

Swedish Nuclear Power Inspectorate. 2005. About the Swedish Nuclear Power Inspectorate. Stockholm, Sweden: SKI.

[http://www.ski.se/extra/tools/parser/index.cgi?url=/html/parse/index_en.html\&select ed $=2 \&$ mainurl $=/$ page $/ 5 / 2 . h t m l]$

Swedish Radiation Protection Authority. 2004. Report on the Activity of the SSI Project for Nuclear Waste Information - Report to the Ministry of the Environment (Translated by G. Leroux). Stockholm, Sweden: SSI.

Thegerström, C., T. Hedman, S.L. Engström and O. Olsson. 2004. Siting a deep geological repository for spent nuclear fuel - A technical endeavour and a social challenge. Lecture at Euradwaste '04, Luxembourg, 29 March 2004. Stockholm, Sweden: Swedish Nuclear Fuel and Waste Management Co (SKB). [http://www.skb.se/upload/Foretaget/Media/Texter/Luxemburg\%202004\%20I.pdf] 
Treichel, J. 2000. "How to Achieve Public Participation in Nuclear Waste Decisions: Public relations or transparent adversary science" in Risk: Health, Safety \& Environment 11:3, pp.221-231.

van den Berg, R.J. and Damveld, H. 2000. Discussions on Nuclear Waste: A survey on public participation, decision-making and discussions in eight countries. Amsterdam, The Netherlands: Laka Foundation.

Victor, M.P. 2003. Key Social Issues Related to Nuclear Waste, or What do Canadians Want To Do About Nuclear Waste? Ottawa, ON: Nuclear Waste Management Organization.

Westerlind, M. and B. Hedberg. 2000. SKI's and SSI's Experiences from Their Participation in the Siting of a Final Repository for Spent Nuclear Fuel. In NEA, 2000.

Wilson, P.D., ed. 1996. The Nuclear Fuel Cycle: From ore to wastes. Oxford: Oxford University Press.

World Nuclear Association. 2001. "The Nuclear Fuel Cycle". http://www.worldnuclear.org/info/inf03.htm. World Nuclear Association. http://www.worldnuclear.org. May 26, 2004.

World Nuclear Association. 2004. "Nuclear Power in the World Today". http://www.world-nuclear.org/info/inf01.htm. World Nuclear Association. http://www.world-nuclear.org. May 26, 2004.

World Nuclear Association. 2004. Canada's Uranium Production and Nuclear Power. London, England: WNA. [http://world-nuclear.org/info/inf49.htm] 